\title{
Agricultural Markets in Benin and Malawi: Operation and Performance of Traders
}

\author{
Marcel Fafchamps \\ World Bank Visiting Research Fellow and Oxford University \\ Eleni Gabre-Madhin \\ International Food Policy Research Institute
}

\begin{abstract}
Based on original trader surveys, this paper examines how agricultural traders operate in two sub-Saharan African countries, Benin and Malawi. Results indicate that the largest transaction costs are search and transport. Search methods rely principally on personal visits by the trader himself or herself, which raises search costs. Since enterprises are very small, transport represents a large share of marketing costs. Brand recognition, grading, and quality certification are non-existent. Brokers and agents are not organized in commodity exchanges. Quantities are not pooled for transport and storage so as to achieve returns to scale. Inter-seasonal and inter-regional arbitrage is outside the purview of most traders, who prefer to operate in a small territory on a day-by-day basis. The information presented here provides some important insights as to how agricultural trade can be improved. Policy interventions can be conceived in four main areas: (i) increasing traders' asset base; (ii) reducing transaction risk; (iii) promoting more sophisticated business practices; and, (iv) reducing physical marketing costs.
\end{abstract}

\section{Acknowledgements}

As part of the IFPRI project on "The Impact of Agricultural Market Reform on Smallholder Farmers in Benin and Malawi," funded by BMZ, this study was conducted in collaboration with the World Bank, which provided funding for the data collection and analysis of agricultural markets. The authors wish to thank the national collaborators, Dr. Bio Goura Soulé of LARES in Benin, and Mr. Richard Kachule of APRU, Bunda College of Agriculture, in Malawi for their research inputs and coordination of the fieldwork. The authors are also grateful to Dr. Mylène Kherallah, project leader, and Dr. Nick Minot of IFPRI for their participation and inputs into the survey design. 


\section{Introduction}

A large number of studies have addressed the question of market integration in the post-market reform era in sub-Saharan Africa (Badiane and Shively, 1998; Dercon, 1995; Negassa and Jayne, 1999). These studies rely primarily on the analysis of price co-movements at the market level. While this type of analysis is highly informative in providing snapshot evidence of market segmentation or lack of price transmission at a given point in time, it does not provide significant insights on why markets are poorly integrated or what constraints are faced by market actors. Relatively few studies have addressed the microeconomic behavior of market participants, such as individual traders or firms (Bryceson, 1993; Barrett, 1997; Gabre-Madhin, 1998; Fafchamps and Minten, 1999). These studies highlight the importance of transaction costs facing individual traders, the role of intermediaries, and of relationships and social capital. Even fewer studies have attempted to link trader characteristics and market behavior with standards of market performance at the trader level.

The present paper fills this gap by documenting traders' assets, their trading practices and commercial activities, and their capacity to undertake spatial and temporal arbitrage. This paper presents original evidence for Benin and Malawi on how traders' assets, including financial, physical, human, and social capital, influence their commercial activities and, ultimately, their arbitrage behavior. An enduring puzzle in the market literature in sub-Saharan Africa is why marketing margins remain high despite reforms and the relative lack of sophistication of liberalized markets (Beynon et al., 1992; Jayne and Jones, 1997).

The approach taken in this paper is to empirically investigate traders' assets and trading practices and link these not only to evidence on traders' gross margins but also to their net margins using detailed data on marketing, operating, and transaction costs. This approach is important for a number of reasons. First, despite reforms, traders in liberalized markets across sub-Saharan Africa continue to operate in an environment of suspicion, viewed by policymakers and laypersons alike as alike as speculative, usurious, or benefiting from excessive profits. Second, an emerging conclusion of the postreform era is that market liberalization is necessary but not sufficient to bring about efficient markets. Thus, a closer look at the individual determinants of performance is warranted. Finally, in the wake of reforms, it remains unclear what is the appropriate role of the public sector. Again, understanding the 
source of the constrained behavior of market participant can serve to highlight areas of where intervention can have an impact, in terms of policy as well as infrastructure and institutions.

This paper is based on the conceptual framework presented in Figure 1. In this framework, policy, institutions, infrastructure are exogenous to the behavior of traders in the market. Thus, policies that limit, regulate, or promote private sector market participation will influence traders' access to and accumulation of assets as well as their business practices, and their commercial activities. Assets, which are specific to individual trading firms, include human resources, physical capital in the form of buildings and equipment, financial assets, and social capital. Trading practices include traders' inspection of goods, methods of payments, their reliance on networks, their use of intermediaries such as agents and brokers, their contractual performance, their search behavior, their enforcement of property rights, and their investment and specialization in agricultural trade. Assets and business practices are also influenced by the existence or lack of formal market institutions such as commercial law and dispute settlement mechanisms, inspection services, referral agencies, trade associations, and information systems. Both assets and practices along with infrastructure, such as roads, vehicle fleets, communications, and public storage facilities, directly influence the extent of traders' commercial activities, viewed in the terms of purchases and sales, as well as their transport, storage, and transformation of agricultural products. Finally, the analysis considers the links between traders' assets and practices as well as their commercial activities on how efficient their market activities are, viewed in terms of the relationship between the costs faced by individual traders and their margins. This broad framework enables the analysis of whether better-endowed traders are more or less efficient, whether larger firms in terms of scale or scope of activities influence efficiency, and the impact of trading practices on commercial behavior, among other possible experiments.

In addition, the paper takes a comparative focus on trader performance between Benin and Malawi, which adds a rich dimension to the analysis. Benin, in francophone West Africa, represents an environment in which private market activity has a long history and in which government intervention has traditionally been limited, with the exception of cotton (Kherallah et al., 2000). In sharp contrast, Malawi, along with others in Eastern and Southern Africa, has had, up to recently, extensive state intervention in marketing and protection of smallholders (Jayne and Jones, 1997). Thus, the 
comparative focus provides insights on the role of history and tradition in shaping trading norms and in asset accumulation.

Figure 1 The Operation of Traders in the Market

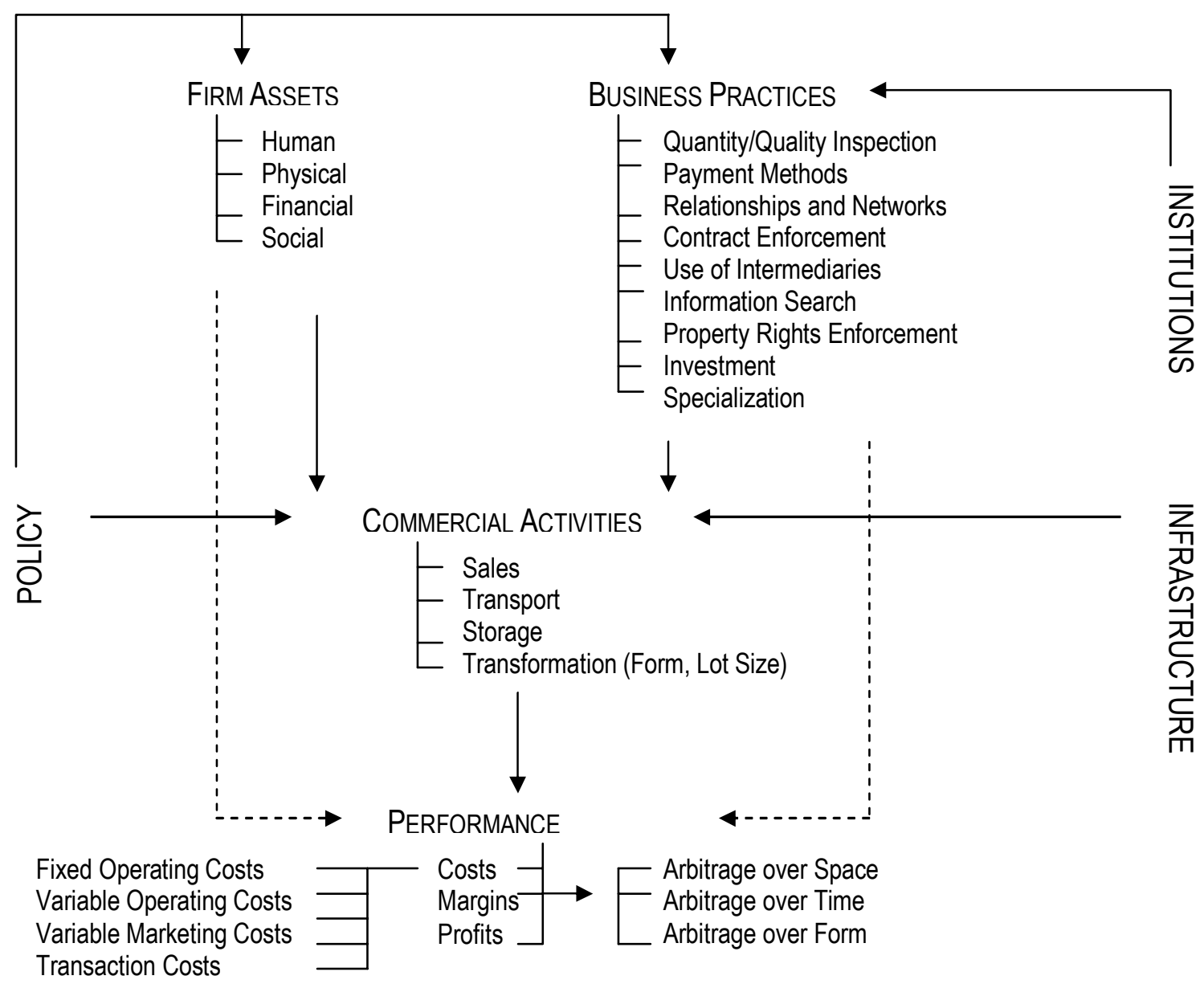




\section{Survey Methodology}

\subsection{Target Population}

In both Benin and Malawi, the survey of traders targeted input traders, food crop traders, and cash crop traders at both the wholesaler and retailer level. In addition, a market-level survey was conducted in order to obtain information on the marketing environment for each of the selected markets in which trader surveys were conducted.

In both countries, food crop traders are primarily independent traders working on their own account, who could be identified by their location in the market. With the exception of cotton, this is also true for cash crop traders in Benin, who often trade in both food and cash crops such as pineapples. However, in Malawi, in the case of tobacco trading, field observations revealed a similar structure of traders operating as agents on behalf of very large tobacco traders. Conversely to the trade of inputs, these traders acted as buying agents, thus buying tobacco from farmers on the account of a large company and delivering the purchased tobacco to the auction floor. Thus, in the case of cash crop trading in Malawi, the survey targeted these buying agents.

\subsection{Survey Site Selection and Sampling Frame}

The survey sites for the trader surveys in both countries are market towns in which a good sample of agricultural traders existed. These market towns were selected on the basis of their importance in the agricultural economy of the country, in terms of flows and volumes of the three types of products: major food crops, cash crops, and agricultural inputs. An additional criterion used to select survey sites was the availability of secondary price data for the market towns. According to these criteria, 24 markets were identified in Benin and 40 markets were identified in Malawi (see Table 1).

In both Benin and Malawi, a sample population of 800 retail and wholesale traders was targeted, broken down into 200 input traders, 200 cash traders, and 400 food crop traders. Due to the absence of reliable census information on the population of traders in both countries, the first step in drawing a random sample was to conduct a census of traders in the selected markets. In Benin, this task proved extremely difficult given the very large number of retailers in the major markets and the mobility of 
traders between market days. Thus, the process followed in Benin to conduct a census of traders was to obtain lists of traders from ONASA (Office National d'Appui à la Sécurité Alimentaire), and the regional bureaus of Ministry of Commerce. In addition to these lists, the survey team undertook a count of traders present on the market day, and used these three sources of information to construct a census from which a sample was randomly draw, resulting in a total sample of 663 food crop and cash crop traders.

In Malawi, a reconnaissance survey of traders was conducted in July-August 1999 in order to count and identify traders according to their status (independent, buying agent, or selling agent), their level (retail or wholesale), and the types of products they traded. The information on the name, type, and location of traders from the reconnaissance survey were entered into a spreadsheet and the sample was drawn randomly from the census data using a computer algorithm. Thus, for the three types of products, a total sample of 738 traders was interviewed in Malawi. Thus, for both countries, the total sample of independent traders is 1371 .

\section{$2.3 \quad$ Survey Instrument}

Initially, a questionnaire was designed for independent agricultural traders in both countries. During the course of field visits, the questionnaire was tailored to the specific market conditions of each country, while at the same time maintaining the same structure and format across the two countries. The coverage of the survey instrument is not only very broad, but also innovative in the type of information gathered. Thus, the trader questionnaire covered the following main areas: (a) defining the trading enterprise; (b) trader characteristics; (c) factors of productions and operating costs; (d) trading activities and marketing costs; (e) relationships and coordination costs. One innovation in the survey instrument is that, in addition to annually constructing volumes of sales, purchases, and storage, the questionnaire also addresses specific arbitrage behavior on the last completed wholesale transaction. Moreover, in contrast to typical market surveys which focus on trading activities and business assets, data were collected on search behavior and costs, quality inspection, contract enforcement and dispute settlement, information, and property rights enforcement. Obtaining this type of data, which are generally more sensitive and culture-specific, involved considerable dialogue with the survey team and focused training. 
Table 1. Survey Sites and Sample Population

\begin{tabular}{|c|c|c|c|c|c|c|c|c|}
\hline \multicolumn{3}{|c|}{ Benin } & \multicolumn{5}{|c|}{ Malawi } & \multirow[b]{2}{*}{ Sample } \\
\hline Department & Market & Sample & Region & Market & Sample & Region & Market & \\
\hline \multirow[t]{5}{*}{ Atacora } & Djougou & 30 & South & Balaka & 16 & Central & Nkhotakota & 2 \\
\hline & Kassouallah & 20 & & Liwonde & 20 & & Salima & 16 \\
\hline & Natitingou & 15 & & Ntaja & 9 & & Dowa & 3 \\
\hline & Tanguieta & 10 & & Mangochi & 29 & & Mponela & 20 \\
\hline & Pehunco & 20 & & Monkey Bay & 4 & & Ntchisi & 14 \\
\hline \multirow[t]{2}{*}{ Atlantique } & Cotonou & 100 & & Chiponde & 34 & & Kasungu & 3 \\
\hline & Sekou & 10 & & Jali & 21 & & Mchinji & 2 \\
\hline \multirow[t]{5}{*}{ Borgou } & Parakou & 65 & & Limbe & 31 & & Lilongwe & 24 \\
\hline & Malanville & 30 & & Lunzu & 63 & & Msundwe & 26 \\
\hline & Nikki & 36 & & Mwanza & 6 & & Mitundu & 50 \\
\hline & Banikouara & 20 & & Nsanje & 24 & & Chimbiya & 8 \\
\hline & Gamia & 15 & & Balunga & 9 & & Njonja & 20 \\
\hline \multirow[t]{2}{*}{ Mono } & Azove & 45 & & Nchalo & 12 & & Thete & 13 \\
\hline & Come & 20 & & Thyolo & 19 & & & \\
\hline \multirow[t]{4}{*}{ Oueme } & Ketou & 41 & & Luchenza & 19 & North & Lizulu & 36 \\
\hline & Pobe & 40 & & Muloza & 28 & & Ntcheu & 22 \\
\hline & Azowilisse & 10 & & Chiringa & 17 & & Chitipa & 20 \\
\hline & Ouando & 36 & & Phalombe & 11 & & Karonga & 13 \\
\hline \multirow[t]{5}{*}{ Zou } & Bohicon & 55 & & & & & Rumphi & 7 \\
\hline & Glazoue & 30 & & & & & Mzuzu & 45 \\
\hline & Ouesse & 15 & & & & & Mzimba & 5 \\
\hline & No. Markets & 21 & & Jo. Markets & & & & 40 \\
\hline & No. Traders & 663 & & Jo. Traders & & & & 738 \\
\hline
\end{tabular}




\section{Business Assets}

\subsection{Financial Resources}

Working Capital. The money traders use to purchase agricultural products and pay marketing costs, their working capital, is fairly large by the standards of the countries concerned: $\$ 1470$ in Benin, $\$ 560$ in Malawi. This is equivalent to two or three times the annual GDP per capita. The median is much smaller, at $\$ 333$ and $\$ 136$, respectively. We see that, contrary to expectations, working capital is 2 to 3 three times larger in Benin than in Malawi: if profits are larger in Malawi, it is not because Malawian traders use more finance. The majority of respondents report augmenting their working capital relative to the previous year.

Table 2. Working Capital of Traders in Benin and Malawi (US \$)

\begin{tabular}{|c|c|c|c|c|c|c|c|}
\hline & \multicolumn{7}{|c|}{ Benin } \\
\hline & Mean & S.d. & Min. & Max. & Median & $\mathrm{N}$ & $\% 0$ \\
\hline Startup capital & 166 & 926 & 0 & 20000 & 50 & 637 & $3.0 \%$ \\
\hline Current capital & 1471 & 9341 & 0 & 216667 & 333 & 655 & $2.3 \%$ \\
\hline Capital last year & 1168 & 7028 & 0 & 166667 & 267 & 620 & $1.9 \%$ \\
\hline \multirow[t]{3}{*}{ Own capital } & 963 & 3099 & 0 & 53333 & 281 & 654 & $5.0 \%$ \\
\hline & \multicolumn{7}{|c|}{ Malawi } \\
\hline & Mean & S.d. & Min. & Max. & Median & $\mathrm{N}$ & $\% 0$ \\
\hline Startup capital & 80 & 342 & 0 & 4773 & 11 & 738 & $0.0 \%$ \\
\hline Current capital & 560 & 1965 & 2 & 34091 & 136 & 738 & $0.0 \%$ \\
\hline Capital last year & 425 & 1351 & 0 & 22727 & 91 & 725 & $0.3 \%$ \\
\hline Own capital & 548 & 1729 & 0 & 25000 & 136 & 738 & $0.7 \%$ \\
\hline
\end{tabular}

${ }^{a}$ At the time of survey, exchange rates used are 1 US $\$=$ CFA 600 and 1 US $\$=$ MK 45. 
Credit. Most working capital comes from internal sources. External finance is extremely limited. Current dues to lenders are but a tiny fraction of working capital. Although one fifth to one third of respondents have a bank account, only a tiny fraction of them has an overdraft facility. Surprisingly, those with an overdraft facility do not appear to make use of it - perhaps because the interest rate is high. Loans from financial institutions are rare and heavily concentrated on a small number of large traders. In Malawi, most formal loans come from a parastatal. The only source of external finance that is used by a sizeable proportion of respondents is loans from friends and relatives $-8 \%$ of the sample in Benin, 21\% in Malawi. But these loans are for relatively small amounts: $\$ 947$ on average in Benin, $\$ 55$ in Malawi.

A large proportion of surveyed traders (50\% in Benin, $75 \%$ in Malawi) know a friend or relative they could borrow from. The amount involved is moderate -- $\$ 250$ to $\$ 300$-- and the average duration of the loan limited to 3 months. Regarding alternative savings instrument, $70 \%$ of Benin traders are member of a rotating saving and credit association (ROSCA) vs. only $2 \%$ in Malawi. Supplier credit is a much more frequent form of credit. We revisit this issue when we discuss relationships with suppliers and clients. 


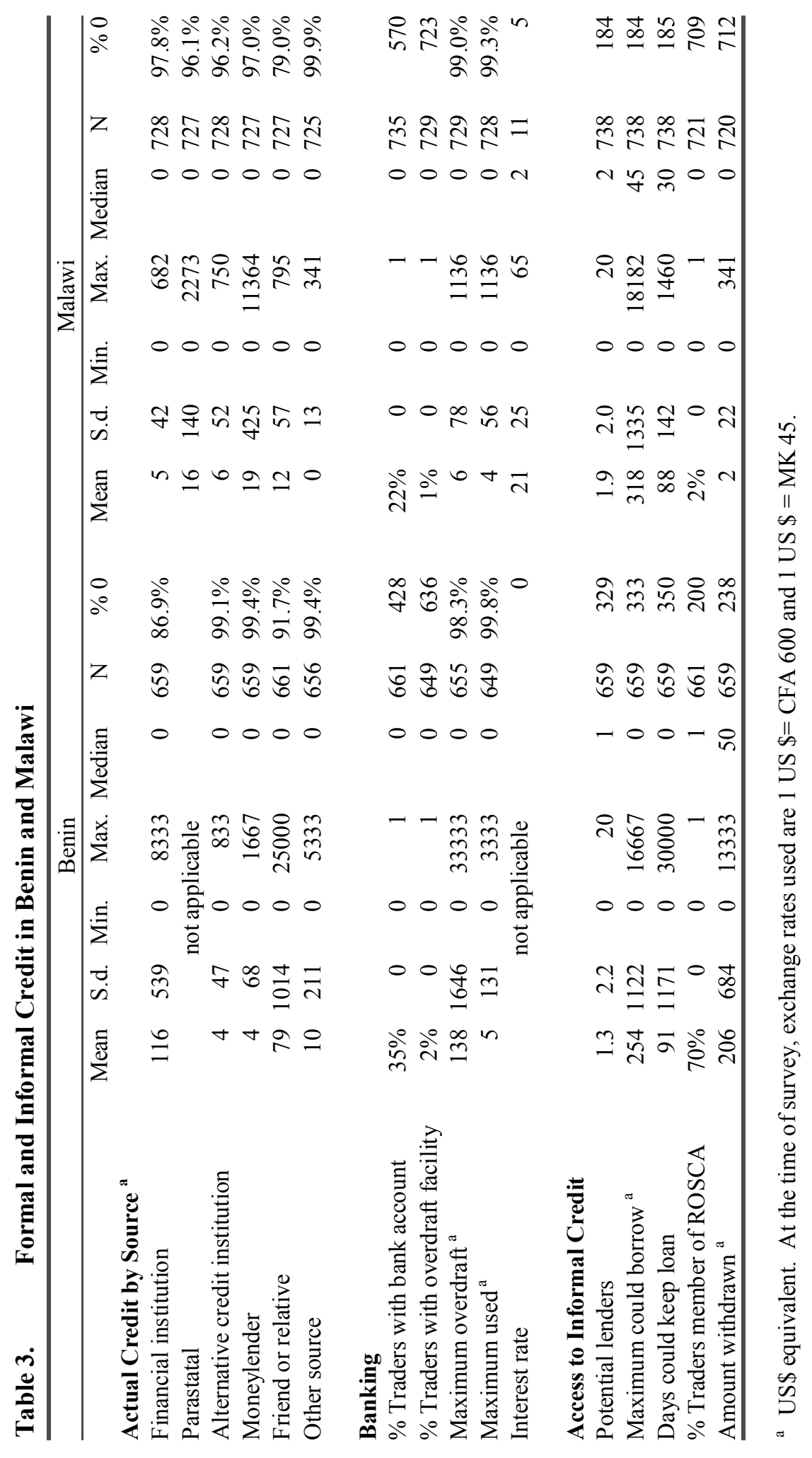





\subsection{Physical Capital}

In terms of equipment, surveyed traders appear surprisingly unequipped. The overwhelming majority of them do not own (serious) weighting equipment, transportation, or storage facilities. Only $3 \%$ of the total sample has a telephone. In terms of value, vehicles are clearly the most important equipment item. But ownership of vehicles is heavily concentrated, with a large proportion of surveyed traders without vehicles -- $85 \%$ and $94 \%$ in Benin and Malawi, respectively. The total value of vehicles is about 9 times higher in Benin than Malawi. Contrary to working capital where we see evidence of increase over time, equipment appears very stable, with virtually no change relative to the previous year-a $6 \%$ increase only in the total number of vehicles, compared to a reported $29 \%$ increase in total working capital.

In terms of buildings, $59 \%$ of Benin traders and $35 \%$ of Malawian traders buy and sell from their residence. Half of them store at their residence as well. In terms of wealth, one a quarter of Benin respondents own their home, vs. three quarters of Malawian respondents. At $\$ 13,700$, the value of a Benin home, however, is about 12 times higher on average than a Malawian home ( $\mathrm{t}$ value of 6.81) -- which may explain why fewer Benin respondents can afford a home. Higher population density and level of urbanization probably account for the difference in property values.

In terms of storage outside of their own residence, $24 \%$ and $39 \%$ of Benin and Malawian traders, respectively, store in a dedicated facility outside their home-either owned or rented from someone else. The combined storage capacity of exclusive use facilities is on average 7 metric tons in Benin and 12 metric tons in Malawi (median of 1.4 tons in both countries). Half of Benin's traders and one third of Malawian traders also have access to a collective storage facility, usually located at or around the market. The cost of storage in these facilities is about 25 cents per day per ton in Benin and 3 in Malawi, which seems high. 
Table 4. Physical Capital and Investment by Traders in Benin and Malawi

\begin{tabular}{|c|c|c|c|c|c|c|c|c|}
\hline \multirow[b]{2}{*}{ \% Traders who own: } & \multicolumn{3}{|c|}{ Benin } & \multicolumn{5}{|c|}{ Malawi } \\
\hline & Mean & S.d. & Median & $\mathrm{N}$ & Mean & S.d. & Median & $\mathrm{N}$ \\
\hline Scales & $8 \%$ & 0 & 0 & 663 & $29 \%$ & 0 & 0 & 738 \\
\hline Processing equipment & $6 \%$ & 0 & 0 & 663 & $1 \%$ & 0 & 0 & 738 \\
\hline Non-motorized transport & $13 \%$ & 0 & 0 & 663 & $58 \%$ & 0 & 1 & 738 \\
\hline Motorized transport & $15 \%$ & 0 & 0 & 663 & $6 \%$ & 0 & 0 & 738 \\
\hline Shop and storage facility & $10 \%$ & 0 & 0 & 663 & $11 \%$ & 0 & 0 & 738 \\
\hline Telephone & $4 \%$ & 0 & 0 & 663 & $1 \%$ & 0 & 0 & 737 \\
\hline \multicolumn{9}{|l|}{ Average number by trader: } \\
\hline Scales & 0.13 & 0.52 & 0 & 663 & 0.51 & 1.71 & 0 & 736 \\
\hline Processing equipment & 0.11 & 0.58 & 0 & 663 & 0.01 & 0.18 & 0 & 738 \\
\hline Non-motorized transport & 0.20 & 0.57 & 0 & 663 & 0.82 & 0.96 & 1 & 737 \\
\hline Motorized transport & 0.32 & 1.04 & 0 & 663 & 0.08 & 0.39 & 0 & 738 \\
\hline Shop and storage facility & 0.13 & 0.44 & 0 & 661 & 0.13 & 0.37 & 0 & 738 \\
\hline Telephone & 0.03 & 0.18 & 0 & 657 & 0.01 & 0.12 & 0 & 737 \\
\hline \multicolumn{9}{|l|}{ Average number a year ago: } \\
\hline Scales & 0.13 & 0.52 & 0 & 663 & 0.47 & 1.68 & 0 & 738 \\
\hline Processing equipment & 0.11 & 0.59 & 0 & 663 & 0.01 & 0.18 & 0 & 738 \\
\hline Non-motorized transport & 0.19 & 0.56 & 0 & 663 & 0.78 & 0.93 & 1 & 738 \\
\hline Motorized transport & 0.30 & 1.02 & 0 & 663 & 0.07 & 0.38 & 0 & 738 \\
\hline Shop and storage facility & 0.12 & 0.43 & 0 & 663 & 0.12 & 0.36 & 0 & 738 \\
\hline Telephone & 0.03 & 0.18 & 0 & 663 & 0.01 & 0.12 & 0 & 738 \\
\hline \multicolumn{9}{|l|}{ Current value of: ${ }^{a}$} \\
\hline Scales & 61 & 305 & 0 & 661 & 46 & 249 & 0 & 736 \\
\hline Processing equipment & 32 & 281 & 0 & 663 & 64 & 1274 & 0 & 738 \\
\hline Non-motorized transport & 21 & 83 & 0 & 659 & 34 & 57 & 23 & 736 \\
\hline Motorized transport & 3277 & 24603 & 0 & 657 & 357 & 3224 & 0 & 738 \\
\hline Shop and storage facility & 106 & 723 & 0 & 648 & 188 & 1174 & 0 & 737 \\
\hline \multicolumn{9}{|l|}{ Value a year ago: ${ }^{a}$} \\
\hline Scales & 61 & 304 & 0 & 663 & 39 & 186 & 0 & 736 \\
\hline Processing equipment & 33 & 281 & 0 & 663 & 16 & 218 & 0 & 738 \\
\hline Non-motorized transport & 20 & 82 & 0 & 663 & 35 & 112 & 20 & 737 \\
\hline
\end{tabular}

US\$ equivalent. At the time of survey, exchange rates used are 1 US $\$=$ CFA 600 and 1 US $\$=$ MK 45 . 


\subsection{Human capital and resources}

Education and Experience. Two thirds of surveyed Benin traders have no education as opposed to only $10 \%$ of Malawian traders. Half of the respondents have worked in another business before initiating the current enterprise. Benin traders are more experienced than their Malawian counterparts with about twice the number of years of experience both in the current enterprise and in a previous business. Benin traders are also much more likely to have worked in their parents' business $(67 \%$ of those with previous business experience) than Malawian traders (4\%). Malawian traders acquired prior experience nearly exclusively through another business of their own. Another difference between the two countries is that one sixth of Benin traders have worked as an agent prior to initiating their current trade operation, vs. only $3 \%$ in Malawi.

With respect to the last occupation prior to becoming involved with agricultural trade, in both countries one third of traders previously worked in agriculture or food processing, one third in trade, and one third in other occupations. Previous trade experience is nearly always in non-agricultural trade in the case of Malawi, against one third of respondents with previous trade experience in Benin. Malawi traders are also more likely to have been wage workers or students prior to entering agricultural trade. Malawi traders arrive to agricultural trade from quite a different starting point. This possibly reflects the impact of trade liberalization. 
Table 5. Human Capital of Traders in Benin and Malawi

\begin{tabular}{|c|c|c|}
\hline & Benin & Malawi \\
\hline \multicolumn{3}{|l|}{ Education (\% of traders) } \\
\hline Trader- no education/ illiterate & 68.08 & 9.90 \\
\hline Mother - no education/illiterate & 97.71 & 26.70 \\
\hline Father- no education/illiterate & 90.40 & 53.20 \\
\hline \multicolumn{3}{|l|}{ Marital status (\% of traders) } \\
\hline Married & 89.26 & 82.20 \\
\hline Single & 3.78 & 7.50 \\
\hline Divorced & 1.82 & 5.00 \\
\hline Widow/er & 5.14 & 5.30 \\
\hline \multicolumn{3}{|l|}{ Traders' Age } \\
\hline Mean (S.d) & 40.71(10.52) & $33.44(9.16)$ \\
\hline $\mathrm{N}$ & 660 & 738 \\
\hline \multicolumn{3}{|l|}{ Number of languages spoken } \\
\hline Mean (S.d) & $2.65(1.39)$ & $2.14(1.15)$ \\
\hline $\mathrm{N}$ & 661 & 738 \\
\hline \multicolumn{3}{|l|}{ Past primary occupation (\% traders) } \\
\hline Agriculture/fishery/livestock & 18.94 & 27.60 \\
\hline Agricultural trade & 23.33 & 2.20 \\
\hline Non-agricultural trade & 11.97 & 30.10 \\
\hline Wage/civil servant & 1.36 & 13.70 \\
\hline Student & 7.88 & 12.20 \\
\hline None/housework & 13.03 & 8.50 \\
\hline
\end{tabular}

Employees. Apart from the trader himself or herself, surveyed enterprises do not employ abundant manpower. The average total manpower of surveyed firms is 2.2 individuals in Benin and 1.5 in Malawi. Most employees are family workers. Non-family employees only amount to 0.4 to 0.5 persons on average. Employment levels also appear extremely stable, with no perceptible trend in employment levels.

Wages paid are very low. A large proportion of family workers receive no wage - around $70 \%$ in Benin, $40 \%$ in Malawi. Non-family workers nearly always receive a wage. Cases when they do not receive a wage probably correspond to apprenticeship contracts. For those non-family workers who receive a wage, the remuneration level is around \$7 per month in Benin and \$27 in Malawi. The large discrepancy in wage levels may be due to the presence of a small number of large, formal employers in Malawi. Contrary to 
micro-enterprises where wages are notoriously low, large African employers pay higher wages (Mazumdar and Mazaheri 1998, Velenchik 1997).

Trading enterprises are not very centralized. In addition to the owner, 1.1 persons on average are authorized to buy for the firm in Benin, and 0.6 persons in Malawi. Similar though slightly lower numbers are reported for those authorized to sell for the firm. Surveyed trading firms operate an average of 4.7 days a week in Benin, vs. 6.1 days a week in Malawi.

On average, the owner is absent for 12 days a year in Benin, and 46 days in Malawi. Absences are mostly motivated by the need for the trader to visit distant purchase and sales market. In most cases, the firm continues to operate in the trader's absence. In the absence of the trader, the business is normally run by an employee of the firm, preferably a relative, in $45 \%$ of the cases in Benin and $17 \%$ in Malawi. It is also very common for the trader to rely on someone external to the firm — either a friend or a relative - to look after the business in his or her absence. This occurs in $48 \%$ of the cases in Benin and $64 \%$ of the cases in Malawi. If such a person cannot be found, the business closes. 


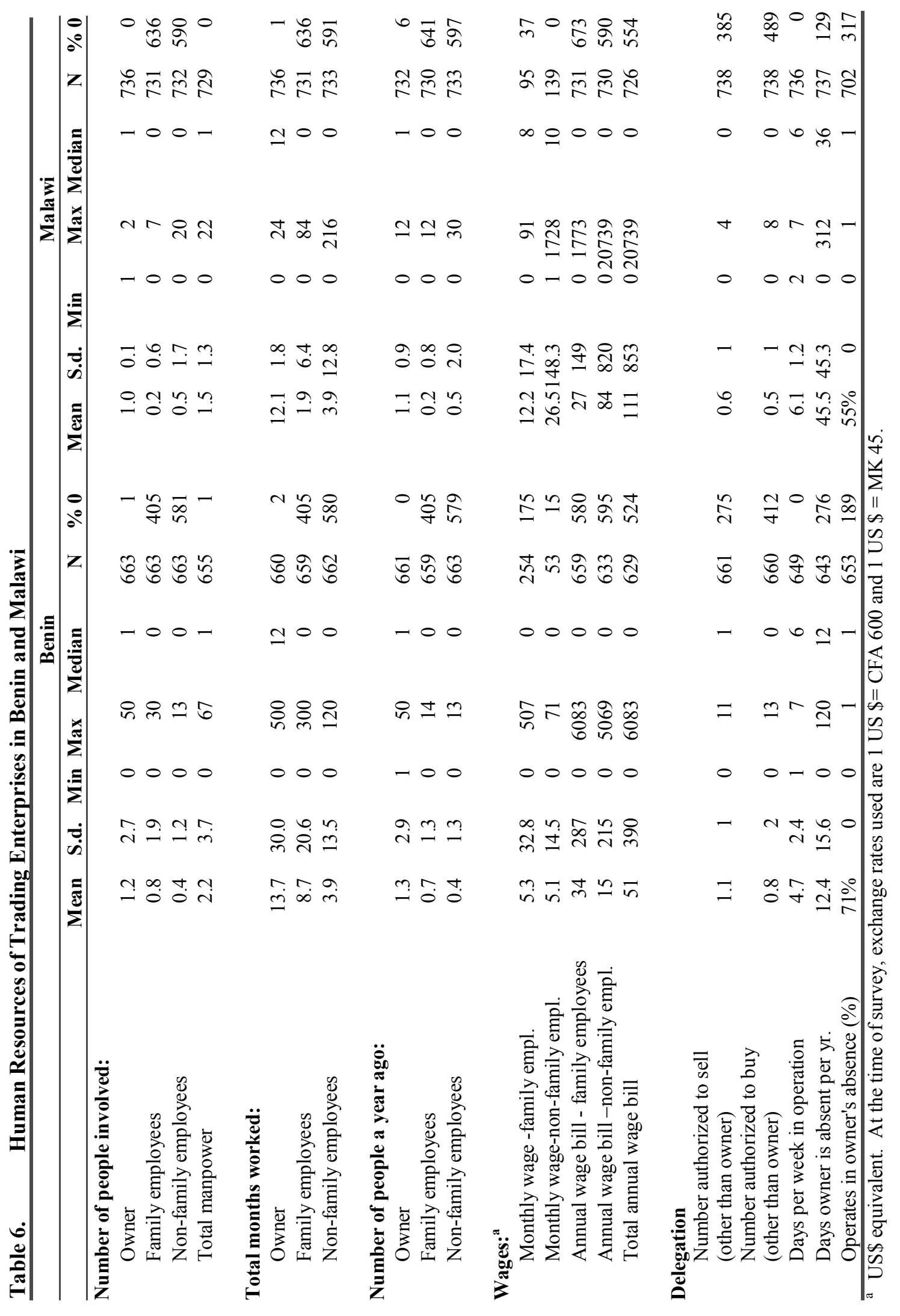





\subsection{Social Capital}

Family. In terms of parental background, the two countries differ little as far as fathers are concerned: they are overwhelmingly farmers. Mothers have different occupations, however, with over half of them involved in trade in Benin vs. ten percent in Malawi. Benin mothers also have a much longer experience in trade than their Malawian counterparts: 21 years of experience on average vs. 9 in Malawi. In terms of gender, $80 \%$ of traders are women vs. $36 \%$ in Malawi, reflecting a long tradition of female involvement in trade along the West African coast.

Family size also differs across the two trader populations, with Benin traders having more sons, daughters, brothers and sisters. Family involvement in trade also varies: Benin traders have more than twice as many close relatives involved in trade than Malawian traders.

Results therefore suggest that involvement in trade is more ancient in Benin. Traders are older, have more experience, and have had much exposure to trade from their parents and close relatives. One would consequently expect Benin traders to be more sophisticated and more efficient. Because their background is very 'traditional', however, the sophistication they can achieve is likely to follow informal avenuesbuilding up social networks, achieving trust through personal relationships (Fafchamps and Minten, 1999, 2000, 2001a).

In contrast, Malawian traders are younger, better educated, and more likely to come from a nonagricultural or wage employment background. We would therefore expect them to be more 'modern', that is, more inclined to experiment with new marketing techniques and modern technology such as motorized vehicles, telephones, and formal contracts. Better education may also enable Malawian traders to delegate authority to subordinates and thus to grow and have larger firms. 
Table 7. Traders' Social Capital: Family

\begin{tabular}{|c|c|c|c|c|c|c|c|c|}
\hline & \multicolumn{3}{|c|}{ Benin } & \multicolumn{5}{|c|}{ Malawi } \\
\hline & Mean & S.d. & & $\mathrm{N}$ & Mean & S.d. & Median & $\mathrm{N}$ \\
\hline \multicolumn{9}{|l|}{ Number: } \\
\hline Live father & 0.46 & 0.70 & 0 & 661 & 0.48 & 0.50 & 0 & 737 \\
\hline Live mother & 0.66 & 0.60 & 1 & 661 & 0.74 & 0.44 & 1 & 737 \\
\hline Spouse & 1.08 & 0.74 & 1 & 661 & 0.82 & 0.41 & 1 & 737 \\
\hline Son over 15 & 1.35 & 1.77 & 1 & 662 & 0.44 & 0.91 & 0 & 737 \\
\hline Daughter over 15 & 1.31 & 1.78 & 1 & 662 & 0.41 & 0.89 & 0 & 737 \\
\hline Brother over 15 & 2.77 & 2.90 & 2 & 657 & 1.85 & 1.39 & 2 & 737 \\
\hline Sister over 15 & 2.62 & 3.02 & 2 & 655 & 1.91 & 1.56 & 2 & 737 \\
\hline \multicolumn{9}{|l|}{$\begin{array}{l}\text { Number in trader's } \\
\text { business: }\end{array}$} \\
\hline Live father & 0.00 & 0.04 & 0 & 661 & 0.00 & 0.04 & 0 & 737 \\
\hline Live mother & 0.04 & 0.20 & 0 & 661 & 0.01 & 0.07 & 0 & 737 \\
\hline Spouse & 0.06 & 0.32 & 0 & 662 & 0.12 & 0.33 & 0 & 737 \\
\hline Son over 15 & 0.12 & 0.55 & 0 & 662 & 0.04 & 0.30 & 0 & 737 \\
\hline Daughter over 15 & 0.23 & 0.63 & 0 & 662 & 0.01 & 0.08 & 0 & 737 \\
\hline Brother over 15 & 0.02 & 0.18 & 0 & 662 & 0.07 & 0.31 & 0 & 737 \\
\hline Sister over 15 & 0.12 & 0.46 & 0 & 661 & 0.01 & 0.12 & 0 & 737 \\
\hline Another relative & 0.34 & 1.14 & 0 & 663 & 0.03 & 0.31 & 0 & 738 \\
\hline \multicolumn{9}{|l|}{$\begin{array}{l}\text { Number in another } \\
\text { trading business: }\end{array}$} \\
\hline Live father & 0.07 & 0.26 & 0 & 661 & 0.08 & 0.27 & 0 & 737 \\
\hline Live mother & 0.27 & 0.56 & 0 & 661 & 0.12 & 0.33 & 0 & 737 \\
\hline Spouse & 0.32 & 0.77 & 0 & 662 & 0.22 & 0.42 & 0 & 737 \\
\hline Son over 15 & 0.13 & 0.53 & 0 & 662 & 0.07 & 0.30 & 0 & 737 \\
\hline Daughter over 15 & 0.32 & 0.95 & 0 & 662 & 0.04 & 0.25 & 0 & 737 \\
\hline Brother over 15 & 0.42 & 1.18 & 0 & 658 & 0.56 & 0.85 & 0 & 737 \\
\hline Sister over 15 & 1.37 & 2.12 & 1 & 657 & 0.33 & 0.75 & 0 & 737 \\
\hline \multicolumn{9}{|l|}{$\begin{array}{l}\text { Number of wage } \\
\text { workers: }\end{array}$} \\
\hline Live father & 0.04 & 0.39 & 0 & 661 & 0.03 & 0.18 & 0 & 737 \\
\hline Live mother & 0.01 & 0.08 & 0 & 661 & 0.00 & 0.06 & 0 & 737 \\
\hline Spouse & 0.22 & 0.90 & 0 & 662 & 0.08 & 0.36 & 0 & 737 \\
\hline Son over 15 & 0.07 & 0.34 & 0 & 662 & 0.07 & 0.33 & 0 & 737 \\
\hline Daughter over 15 & 0.05 & 0.37 & 0 & 662 & 0.02 & 0.20 & 0 & 737 \\
\hline Brother over 15 & 0.39 & 1.08 & 0 & 659 & 0.34 & 0.69 & 0 & 737 \\
\hline Sister over 15 & 0.08 & 0.43 & 0 & 657 & 0.09 & 0.34 & 0 & 737 \\
\hline
\end{tabular}


Trading Contacts and Associations. We find that respondents know on average 37 to 42 other traders split more or less equally between purchase and sales markets. Medians are 23 for Benin and 20 for Malawi. The two countries, however, differ in the number of traders respondent knew at start-up: 17 on average in Benin vs. 6 only in Malawi. This is undoubtedly a reflection of the fact that Benin respondents had much more prior exposure to agricultural trade than their Malawian counterparts.

The two countries also differ in the extent of associative life. Two thirds of Benin traders are member of a trader association compared to only $3 \%$ of Malawian traders. They have been members for 7 years on average instead of 3 in Malawi, and Benin associations count many more members -- 188 on average vs. 29 in Malawi. Benin traders agree to pay association fees equivalent to $\$ 6$ a year, while Malawian traders pay nothing. The average number of association members who are also trading partners of the respondent is 34 in Benin compared to 7 only in Malawi. Traders' associations thus play a much more prominent role in Benin.

Regarding the perceived advantages of being part of an association, by far the most important reasons are internal to the traders' community: access to market information; mutual insurance; resolution of commercial disputes. These reasons account for $55 \%$ of the responses in Benin and $46 \%$ in Malawi. Restricting competition is also in traders' mind, especially in Benin: $29 \%$ of Benin traders and $16 \%$ of Malawian traders cite various restrictions on competition (e.g., price fixing, restricting entry, coordinating purchases and sales) as the main advantage their derive from their membership in traders' associations. Dealing with external forces is also an important motivation (e.g., negotiating with government, access to credit, group orders). It accounts for 15\% (Benin) and 35\% (Malawi) of the responses. 
Table 8. Traders' Social Capital: Contacts and Associations

\begin{tabular}{|c|c|c|c|c|c|c|c|c|}
\hline & \multicolumn{3}{|c|}{ Benin } & \multicolumn{5}{|c|}{ Malawi } \\
\hline & Mean & S.d. & Median & $\mathrm{N}$ & Mean & S.d. & Median & $\mathrm{N}$ \\
\hline$\%$ Traders member of association & $62.4 \%$ & 0.48 & 1 & 659 & $3.1 \%$ & 0.17 & 0 & 737 \\
\hline Number of associations & 1.2 & 0.66 & 1 & 413 & 1.1 & 0.29 & 1 & 22 \\
\hline Years of membership & 7 & 8 & 4 & 411 & 3 & 3 & 3 & 22 \\
\hline Annual membership fees ${ }^{\mathrm{a}}$ & 6 & 33 & 0 & 657 & 0 & 3 & 0 & 736 \\
\hline Number of members & 188 & 182 & 120 & 293 & 29 & 30 & 12 & 21 \\
\hline Number of trading partners & 34 & 90 & 2 & 395 & 7 & 12 & 4 & 22 \\
\hline \multicolumn{9}{|l|}{ Advantages to Membership (\% traders) } \\
\hline Access to credit & 8.53 & & & & 22.81 & & & \\
\hline Access to market information & 11.58 & & & & 15.79 & & & \\
\hline Commercial contacts & 5.48 & & & & 8.77 & & & \\
\hline Commercial dispute resolution & 11.66 & & & & 15.79 & & & \\
\hline Negotiate with government & 4.53 & & & & 10.53 & & & \\
\hline Credibility & 3.83 & & & & 5.26 & & & \\
\hline $\begin{array}{l}\text { Protection against unfair } \\
\text { competition }\end{array}$ & 0.44 & & & & 5.26 & & & \\
\hline Agree on prices & 13.84 & & & & 1.75 & & & \\
\hline Group orders & 1.48 & & & & 1.75 & & & \\
\hline Mutual insurance & 22.19 & & & & 0.00 & & & \\
\hline License fee & 3.22 & & & & 1.75 & & & \\
\hline Coordinate purchases and sales & 11.40 & & & & 7.02 & & & \\
\hline Other & 1.83 & & & & 3.51 & & & \\
\hline
\end{tabular}

US\$ equivalent. At the time of survey, exchange rates used are 1 US \$= CFA 600 and 1 US $\$=$ MK 45. 


\section{Trading Practices}

\subsection{Specialization}

Specialization by Crop. Surveyed traders deal primarily in maize, beans, and roots and tubers. Together, these crops account for 80 to $90 \%$ of the main crops traded. None of the surveyed Benin traders deals in cotton, the main cash crop of the country. Cotton marketing remains entirely in the hands of the government marketing board. A small number of surveyed Malawian traders deal in tobacco, the principal export crop. This is the result of a recent liberalization in tobacco marketing. Less than five surveyed traders sell chemical inputs such as fertilizer or pesticides. Agricultural inputs are typically sold either by ADMARC or by local branches of large trading operations.

Table 9. $\quad$ Agricultural Products Traded by Region in Malawi (average shares of total sales by region)

\begin{tabular}{|c|c|c|c|c|c|}
\hline & & South & Central & North & Country-wide \\
\hline Maize & & $26.00 \%$ & $30.80 \%$ & $24.00 \%$ & $27.40 \%$ \\
\hline Irish potato & & $3.20 \%$ & $3.00 \%$ & $1.30 \%$ & $2.90 \%$ \\
\hline Sweet potato & & $9.90 \%$ & $4.70 \%$ & $7.30 \%$ & $7.80 \%$ \\
\hline Cassava & & $7.80 \%$ & $3.50 \%$ & $3.30 \%$ & $5.70 \%$ \\
\hline Rice & & $12.30 \%$ & $1.70 \%$ & $24.70 \%$ & $10.20 \%$ \\
\hline Beans/pulses & & $30.90 \%$ & $28.00 \%$ & $24.00 \%$ & $29.00 \%$ \\
\hline Gr/nuts & & $7.60 \%$ & $4.70 \%$ & $15.30 \%$ & $7.60 \%$ \\
\hline Tobacco & & $1.50 \%$ & $14.40 \%$ & & $5.80 \%$ \\
\hline Chili & & $0.20 \%$ & & & $0.10 \%$ \\
\hline Soyabeans & & $0.30 \%$ & $7.90 \%$ & & $3.00 \%$ \\
\hline & Total & $100.00 \%$ & $100.00 \%$ & $100.00 \%$ & $100.00 \%$ \\
\hline & $\mathrm{N}$ & 593 & 403 & 150 & 1146 \\
\hline
\end{tabular}


Table 10. Agricultural Products Traded by Region in Benin (average shares of total sales by region)

\begin{tabular}{|c|c|c|c|c|c|c|c|}
\hline & \multicolumn{6}{|c|}{ Region } & \multirow[t]{2}{*}{$\begin{array}{l}\text { Country- } \\
\text { wide }\end{array}$} \\
\hline & Atacora & Atlantique & Borgou & Mono & Oueme & Zou & \\
\hline Maize & 24.05 & 38.93 & 26.36 & 47.37 & 45.41 & 42.13 & 34.05 \\
\hline Sorghum/millet & 20.27 & 1.34 & 17.86 & & & 2.03 & 10.22 \\
\hline Small millet & 1.37 & & 1.53 & & & 1.02 & 0.90 \\
\hline Rice & 9.62 & 0.67 & 4.79 & & 0.44 & 0.51 & 3.68 \\
\hline Beans/pulses & 15.12 & 9.40 & 7.41 & 38.60 & 17.47 & 11.17 & 13.76 \\
\hline Groundnuts & 13.75 & 2.68 & 3.49 & 9.65 & 1.75 & 11.68 & 6.81 \\
\hline Bambara groundnuts & 0.69 & 0.67 & 0.22 & & 0.44 & 3.05 & 0.76 \\
\hline Soy & & 0.67 & 0.65 & & & 2.03 & 0.56 \\
\hline Manioc & 1.72 & & 0.22 & & & & 0.42 \\
\hline Yams & 2.41 & 10.07 & 10.89 & & 3.49 & 8.63 & 6.74 \\
\hline Fruit & & & 0.22 & & 0.44 & & 0.14 \\
\hline Tomatoes & 0.69 & 0.67 & 0.87 & & 3.06 & 0.51 & 1.04 \\
\hline Onion & 0.34 & 0.67 & 1.53 & & 0.44 & 3.05 & 1.11 \\
\hline Gombo & & & 0.22 & & & & 0.07 \\
\hline Chili & & 4.03 & 1.74 & 0.88 & 4.37 & & 1.74 \\
\hline Other vegetables & & & 0.65 & & & & 0.21 \\
\hline Other crops & 5.84 & & 7.19 & & 5.24 & 0.51 & 4.38 \\
\hline Pineapple & & 0.67 & & & & & 0.07 \\
\hline Cashew nut & & & 1.09 & & 0.44 & 0.51 & 0.49 \\
\hline Cassava & 1.03 & 20.81 & 4.79 & 3.51 & 16.16 & 11.68 & 8.34 \\
\hline Cossette yams & 1.03 & 4.70 & 6.75 & & 0.44 & 1.52 & 3.13 \\
\hline Cossette manioc & 2.06 & 4.03 & 1.53 & & 0.44 & & 1.39 \\
\hline Total \% & 100.00 & 100.00 & 100.00 & 100.00 & 100.00 & 100.00 & 100.00 \\
\hline $\mathrm{N}$ & 351 & 432 & 515 & 242 & 500 & 269 & 2309 \\
\hline
\end{tabular}

Specialization by Activity. Some traders -- 12\% in Benin, $25 \%$ in Malawi-sell products other than agricultural, but on average surveyed traders derive $95 \%$ of their trade revenue from agricultural trade. Traders are thus moderately specialized by sector. But they do not specialize by crop: two thirds of all surveyed traders sell more than one agricultural product; $45 \%$ sell more than two. In addition, $23 \%$ (Malawi) to $30 \%$ (Benin) of traders have an activity other than trade. In Benin, this activity is overwhelmingly farming; in Malawi, it is overwhelmingly non-agricultural trade. Nearly all traders have a principal market from which they organize their activities. In that market, most of them have a place—stall, store, shed -- for their exclusive usage. Three quarters of surveyed traders also operate in other markets - on average 1.3 to 
1.6 purchase markets and 0.3 to 0.5 sales markets. This suggests that traders normally base their operation at their sales market and purchase from one or two other markets.

Specialization by Trading Function. Traders are not fully specialized by function in the marketing chain. Most traders are retailers but half of Benin retailers and a quarter of Malawian retailers also operate as wholesalers. One sixth of Benin traders and one fourth of Malawian traders specialize in wholesale only. Most traders purchase at least some of the quantities they sell directly from farmers. In fact, $48 \%$ and $74 \%$ of all retailers in Benin and Malawi, respectively, purchase from farmers. This apparent lack of functional specialization makes it hazardous to categorize respondents by their function in the marketing chain. A very small proportion of surveyed traders also operate as buying or selling agent for other traders.

Table 11. Specialization of Traders in Benin and Malawi

\begin{tabular}{lcrrr}
\hline & Benin & \multicolumn{2}{c}{ Malawi } \\
\hline \% Traders: & Mean & S.d. & Mean & S.d. \\
Sell wholesale & & & & $49 \%$ \\
Sell retail & $69 \%$ & $46 \%$ & $40 \%$ & $39 \%$ \\
Purchase from farmers & $74 \%$ & $44 \%$ & $82 \%$ & $28 \%$ \\
With a principal market & $70 \%$ & $46 \%$ & $92 \%$ & $0 \%$ \\
With a place for exclusive use & $98 \%$ & $13 \%$ & $100 \%$ & $25 \%$ \\
Operate in other markets & $74 \%$ & $44 \%$ & $93 \%$ & $41 \%$ \\
Operate as buying agent & $70 \%$ & $46 \%$ & $78 \%$ & $14 \%$ \\
Operate as consignment agent & $6 \%$ & $24 \%$ & $2 \%$ & $10 \%$ \\
Operate as broker & $2 \%$ & $12 \%$ & $1 \%$ & $12 \%$ \\
Sell products other than agricultural & $1 \%$ & $11 \%$ & $1 \%$ & $43 \%$ \\
& $12 \%$ & $33 \%$ & $25 \%$ & 1.1 \\
Number of other purchase markets & & & & 0.3 \\
Number with exclusive use & 1.6 & 1.3 & 1.3 & 0.6 \\
Number of other sales markets & 0.4 & 0.9 & 0.1 & 0.2 \\
Number with exclusive use & 0.5 & 0.8 & 0.3 & 19 \\
Percentage of revenue from ag. trade & 0.3 & 0.6 & 0.0 & 92 \\
\hline
\end{tabular}




\subsection{Firm Ownership}

The overwhelming majority of independent trading enterprises are held in sole ownership by a local resident who is also a national of the country studied. Only 30 of the 1400 surveyed traders are foreign nationals, of which all except one are African. The owner has typically initiated the business himself or herself. The overwhelming majority of respondents initiated the enterprise themselves without help from anyone. Ten to twenty percent of respondents received financial assistance from their family at start-up. For those respondents who did not start the business themselves, they either inherited it or received it as a gift. Virtually no one purchased their enterprise, suggesting that goodwill and reputation are not attached to a specific location, trademark, or business name (Tadelis, 1999). A similar survey in Madagascar indeed showed that African agricultural traders never sell under a trademark or business name (Fafchamps and Minten, 1999).

Table 12. Ownership of Trading Enterprises in Benin and Malawi

\begin{tabular}{|c|c|c|c|c|c|c|}
\hline & \multicolumn{3}{|c|}{ Benin } & \multicolumn{3}{|c|}{ Malawi } \\
\hline & Mean & S.d. & Median & Mean & S.d. & Median \\
\hline$\%$ of firms where manager is owner & $97 \%$ & & & $100 \%$ & & \\
\hline \multicolumn{7}{|l|}{$\%$ of firms where owned by: } \\
\hline Local resident & 99.7 & 3.8 & 100.0 & 97.2 & 16.3 & 100.0 \\
\hline Resident from another town & 0.3 & 3.8 & 0.0 & 2.8 & 16.3 & 0.0 \\
\hline Other & 0.0 & 0.0 & 0.0 & 0.0 & 0.0 & 0.0 \\
\hline \multicolumn{7}{|l|}{ Management of firms: } \\
\hline$\%$ where manager in charge & $97 \%$ & $18 \%$ & $100 \%$ & $100 \%$ & $5 \%$ & $100 \%$ \\
\hline$\%$ where manager responsible for purchases & $99 \%$ & $11 \%$ & $100 \%$ & $100 \%$ & $5 \%$ & $100 \%$ \\
\hline$\%$ where manager responsible for sales & $99 \%$ & $10 \%$ & $100 \%$ & $99 \%$ & $12 \%$ & $100 \%$ \\
\hline Number of years respondent is in operation & 15 & 9 & 13 & 7 & 6 & 5 \\
\hline Number of years respondent is in charge & 15 & 9 & 13 & 7 & 6 & 5 \\
\hline$\%$ Firms where owner started the business & $92 \%$ & $27 \%$ & $100 \%$ & $99 \%$ & $10 \%$ & $100 \%$ \\
\hline$\%$ Managers who worked in another business & $56 \%$ & $50 \%$ & $100 \%$ & $51 \%$ & $50 \%$ & $100 \%$ \\
\hline Number of years of experience elsewhere & 5 & 6 & 4 & 2 & 4 & 0 \\
\hline$\%$ Managers who worked as agent before & $15 \%$ & $36 \%$ & $0 \%$ & $3 \%$ & $18 \%$ & $0 \%$ \\
\hline Number of years of experience as agent & 1 & 3 & 0 & 0 & 1 & 0 \\
\hline \multicolumn{7}{|l|}{ Characteristics of firm owner: } \\
\hline Age & 41 & 11 & 40 & 33 & 9 & 32 \\
\hline$\%$ Women & $81 \%$ & & & $36 \%$ & & \\
\hline
\end{tabular}


Years of trade experience of father

Years of trade experience of mother

$\%$ Engaged in activity other than trade

12

19

\begin{tabular}{rrrr}
0 & 6 & 10 & 0 \\
25 & 5 & 9 & 0 \\
& $23 \%$ & & \\
\hline
\end{tabular}

\subsection{Quantity Inspection: Weights and measures}

Given that only a handful of traders have proper weighting equipment, most trade takes place by volume. In practice, volume may be a better way of measuring the value of an agricultural product than weight. Indeed, the weight of a crop can be artificially inflated by adding water. Since excess moisture raises storage losses, buying by weight generates adverse incentives for farmers not to dry their crops properly before offering them for sale. Most crops also tend to dessicate over time without losing (much) of their caloric content. Since water can be added when food is prepared for consumption, this is usually not a problem - at least for cereals, pulses, groundnuts, roots and tubers. The same holds for most cash crops. The main exception is fruits and vegetables. By focusing on volume instead of weight, traders insure themselves against most storage losses, which are weight losses due to desiccation.

In the two studied countries, burlap and plastic bags of various sizes serve as measures of volume. The weight in a given bag obviously varies by crop but, for a given crop, a standardized-size bag can serve as measurement unit. No less than 11 different types of bag sizes are used in the two studied countries. The bags are usually named after the amount of maize they would contain-from $20 \mathrm{~kg}$ to $200 \mathrm{~kg}$. Benin favors $100 \mathrm{~kg}$ and $200 \mathrm{~kg}$ bags; Malawi favors $50 \mathrm{~kg}, 70 \mathrm{~kg}$, and $90 \mathrm{~kg}$ bags. Weight measures such as $\mathrm{kg}$ or ton are used as well, but in less than $10 \%$ of all purchases.

In practice, burlap and plastic bags are not perfect measures of volume. The first reason is that burlap bags tend to loosen over time so that older bags tend to contain more than new ones. The second reason is that the volume contained in a bag varies with the way it is filled and sealed. Measures are thus somewhat subjective in the sense that they depend on the state of the traders' bags and on the way they are filled. This subjectivity may explain why traders nearly always transfer purchased goods from the bags of the seller to their own bags. This is a time-consuming and cumbersome process, but it may be essential to an 
assessment of volume by the buyer. It also enables the buyer to assess the quality of the product since, in the transfer process, what was at the bottom of the seller's bag ends at the top of the buyer's.

\subsection{Quality Inspection}

We begin by noting that surveyed traders trade in non-standardized products. By their own account, three quarters of surveyed traders deal in products with multiple varieties. Two third also state that the product they sell varies by quality. Variation in variety and quality is associated with price differences. The coefficient of variation of prices due to quality and variety differences is 0.13 in Benin and 0.10 in Malawi (median 0.12 and 0.07 ). This means that a trader could lose most of his or her margin by purchasing a product of poor quality or of the wrong variety. Assessment of the product is thus essential.

Direct inspection is the only method by which surveyed traders assess quality. Only a handful of traders (10 out of more than 2000 responses) declare relying on the supplier to identify the variety and assess the quality. Only one respondent stated that he relies on the package. This finding is similar to those reported by Fafchamps and Minten (1999) for Madagascar. It stands in contrast with results reported by Tripp and Pal (1998) regarding agricultural seeds in India. Inspecting each purchased load for quality is likely to be time-consuming. Since it requires experience and familiarity, it may be hazardous to delegate this function to inexperienced or unmotivated employees. Quality control is thus likely to represent a major obstacle on business expansion.

\subsection{Relationships with suppliers and clients}

Another important dimension of trade as a business is the relationships traders have with their suppliers and clients. The overwhelming majority of surveyed traders have regular clients and suppliers. The number of regulars is fairly large: 6.5 regular suppliers and 7 clients in Benin; 11 suppliers and 15 clients in Malawi. Respondents do close to half of their business with these few individuals. Trade is thus very personalized. Networks of traders play an important role in the movement of agricultural products. 
As far as the composition of these networks is concerned, ethnic concentration appears less prevalent than often assumed (Fafchamps, 1999). Less than half the regular suppliers and clients are from the same ethnic group or religion as the respondent. Only a tiny proportion of regulars are relatives. Contrary to what is claimed by Granovetter (1995) regarding immigrant business networks in the U.S., business relationships among African traders are not primarily built on the family. (Fafchamps and Minten, 2000)

Respondents meet outside business with about a quarter of their regular suppliers and clients in Benin, but only 8 to $15 \%$ of them in Malawi. Social interaction is primarily through business. Some $12 \%$ of Benin suppliers and clients sell exclusively to or buy exclusively from the respondent. The equivalent figure for Malawi is $23 \%$. In contrast, respondents nearly never see themselves as bound to buy only from or sell only to regulars.

Table 13. Traders' Relationships with Regular Partners in Benin and Malawi

\begin{tabular}{lrrrr}
\hline & Benin & & Malawi \\
\hline & Suppliers & Clients & Suppliers & Clients \\
\hline \% Traders that have regular clients or suppliers & $79 \%$ & $69 \%$ & $74 \%$ & $88 \%$ \\
\% Regulars of same origin & $90 \%$ & $87 \%$ & $67 \%$ & $92 \%$ \\
\% Regulars of same ethic group & $47 \%$ & $49 \%$ & $41 \%$ & $45 \%$ \\
\% Regulars of same religion & $43 \%$ & $40 \%$ & $29 \%$ & $36 \%$ \\
\% Regulars with whom meet socially & $26 \%$ & $28 \%$ & $8 \%$ & $15 \%$ \\
\% Regulars that are close relatives & $5 \%$ & $6 \%$ & $4 \%$ & $7 \%$ \\
\% Regulars that have exclusive relations & $12 \%$ & $12 \%$ & $22 \%$ & $23 \%$ \\
\% Traders can sell or buy with non-regulars & $99 \%$ & $99 \%$ & $99 \%$ & $99 \%$ \\
& & & & \\
Number of regulars in main market & $2.7(6.1)$ & $6.5(10.1)$ & $5(15)$ & $14(23)$ \\
Number of regulars in other markets & $3.9(6.4)$ & $0.8(4.0)$ & $6(15)$ & $1(11)$ \\
\% of total trade with regulars & $51(33)$ & $37(32)$ & $45(34)$ & $50(29)$ \\
\hline
\end{tabular}

\subsection{Payment Methods and Trade Credit}

Regarding transaction methods, payment in cash is universal. Payment in foreign currency or in kind occurs very occasionally. Payment by check is unheard of, indicating the lack of sophistication of banking methods by traders and also perhaps the lack of trust among traders. 
Table 14. Payment Methods in Agricultural Trading in Benin and Malawi

\begin{tabular}{lrrrrrr}
\hline & \multicolumn{2}{c}{ Benin } & \multicolumn{4}{c}{ Malawi } \\
\hline & Mean & S.d. & $\mathrm{N}$ & Mean & S.d. & $\mathrm{N}$ \\
\hline Of transactions with suppliers: & & & & & & \\
\% Cash, local currency & 99.5 & 5.1 & 662 & 99.2 & 6.4 & 738 \\
\% Other currency & 0.5 & 5.1 & 662 & 0.4 & 5.5 & 738 \\
\% Wire transfer & 0.0 & 0.0 & 662 & 0.0 & 0.3 & 738 \\
\% Check & 0.0 & 0.0 & 662 & 0.0 & 0.0 & 738 \\
\% In kind & 0.0 & 0.0 & 662 & 0.4 & 3.2 & 738 \\
& & & & & & \\
Of transactions with clients: & & & & & & \\
\% Cash, local currency & 99.9 & 1.9 & 660 & 98.1 & 11.6 & 738 \\
\% Other currency & 0.1 & 1.6 & 660 & 0.5 & 6.3 & 738 \\
\% Wire transfer & 0.0 & 1.2 & 660 & 0.0 & 0.0 & 738 \\
\% Check & 0.0 & 0.0 & 660 & 1.3 & 9.5 & 738 \\
\% In kind & 0.0 & 0.0 & 660 & 0.1 & 0.9 & 738 \\
\hline
\end{tabular}

Supplier credit is moderately common in Benin but fairly rare in Malawi. In Benin, respondents state that close to one quarter of their purchases and sales are made on credit. Sixty percent of respondents claim to be given credit by at least some of their suppliers. Three quarters of them extend credit to at least some of their clients. Corresponding numbers in Malawi are much lower: purchases on credit account for only $3 \%$ of total purchases; credit sales amount to only $11 \%$ of all sales. Some $85 \%$ of Malawian traders claim to never receive credit from suppliers; one third never grant any credit to clients. 
Table 15. Incidence of Trade Credit and Advance Payments to Farmers

\begin{tabular}{|c|c|c|c|c|c|c|c|c|}
\hline & \multicolumn{4}{|c|}{ Benin } & \multicolumn{4}{|c|}{ Malawi } \\
\hline & Mean & S.d. & Median & $\mathrm{N}$ & Mean & S.d. & dian & $\mathrm{N}$ \\
\hline \multicolumn{9}{|l|}{ Of purchases from suppliers: } \\
\hline$\%$ Credit & 23 & 26 & 20 & 662 & 3 & 11 & 0 & 737 \\
\hline \%Payment upon delivery & 74 & 27 & 80 & 662 & 95 & 13 & 100 & 737 \\
\hline \%Advance payment & 4 & 9 & 0 & 662 & 2 & 7 & 0 & 737 \\
\hline \multicolumn{9}{|l|}{ Of sales to clients: } \\
\hline$\%$ Credit & 23 & 24 & 20 & 660 & 11 & 14 & 5 & 738 \\
\hline$\%$ Payment upon delivery & 76 & 24 & 80 & 660 & 87 & 19 & 90 & 738 \\
\hline \%Advance payment & 0 & 4 & 0 & 660 & 0 & 3 & 0 & 738 \\
\hline \multicolumn{9}{|l|}{ Advances to Farmers } \\
\hline$\%$ Traders buy with advance & 24 & & & 654 & & & & \\
\hline \multicolumn{9}{|l|}{ Account payable: ${ }^{a}$} \\
\hline Currently due & 24 & 116 & 0 & 486 & 0 & 4 & 0 & 731 \\
\hline Maximum due & 310 & 855 & 33 & 663 & 8 & 46 & 0 & 738 \\
\hline \multicolumn{9}{|l|}{ Account receivable: } \\
\hline Currently due & 1 & 10 & 0 & 280 & 5 & 47 & 0 & 734 \\
\hline Maximum due & 69 & 385 & 0 & 663 & 32 & 265 & 0 & 738 \\
\hline
\end{tabular}

a US\$ equivalent. At the time of survey, exchange rates used are 1 US $\$=$ CFA 600 and 1 US $\$=$ MK 45.

Outstanding balances on trade credit are very small: \$24 in Benin, nothing in Malawi. This is probably because trade credit is of very short duration: 6 to 8 days on average with suppliers, 9 to 11 days on average with clients. In the overwhelming majority of cases, traders do not charge a different price if they sell cash or on credit. Discussions with respondents suggest that sales on credit correspond to large quantities. Credit seems to be used to incite the buyer to buy more. In this context, waiving interest on trade credit is like offering a quantity discount.

Some traders also extend credit to farmers: $25 \%$ of traders in Benin, less than $10 \%$ in Malawi. Purchases with advance payment to farmers represent a minute proportion of total purchases -- $4 \%$ in Benin, $2 \%$ in Malawi. Crop prices are either set in advance (40\% of the cases in Benin, $75 \%$ in Malawi) or set equal to the market price at the time of delivery. Prices are negotiated at delivery only in a handful of cases. Only in 16 to $24 \%$ of the cases do credit and cash differ. When they do, median cash prices are $13 \%$ higher than credit prices. We therefore find little evidence that advances to farmers hide 'exploitative' practices by traders (Crow and Murshid 1994). 
Table 16. Contractual Terms of Trade Credit and Advance Payments

\begin{tabular}{|c|c|c|c|c|c|c|}
\hline & \multicolumn{6}{|c|}{ Benin } \\
\hline & Mean & S.d. & Min. & Max. & Median & $\mathrm{N}$ \\
\hline \multicolumn{7}{|l|}{ Credit from suppliers } \\
\hline Days to pay & 8.13 & 6.32 & 2.00 & 100.00 & 7.00 & 379 \\
\hline$\%$ Traders pay different price & 5.9 & & & & & 409 \\
\hline$\%$ Credit premium & 8.06 & & & & & 24 \\
\hline \multicolumn{7}{|l|}{ Credit to clients } \\
\hline Days to pay & 9.09 & 13.48 & 1.00 & 279.00 & 7.00 & 469 \\
\hline$\%$ Traders pay different price & 7.8 & & & & & 498 \\
\hline$\%$ Credit premium & 6.06 & & & & & 40 \\
\hline \multicolumn{7}{|l|}{ Advance payment to farmers } \\
\hline Days to pay & 13.70 & 19.55 & 2.00 & 90.00 & 7.00 & 20 \\
\hline$\%$ Traders pay different price & 16 & & & & & 151 \\
\hline \multicolumn{7}{|l|}{ Determination of price } \\
\hline$\%$ Market price at delivery & 58 & & & & & 157 \\
\hline$\%$ Price set forward & 40 & & & & & 157 \\
\hline \multirow[t]{3}{*}{$\%$ Advance discount } & 12.50 & & & & & 28 \\
\hline & \multicolumn{6}{|c|}{ Malawi } \\
\hline & Mean & S.d. & Min. & Max. & Median & $\mathrm{N}$ \\
\hline \multicolumn{7}{|l|}{ Credit from suppliers } \\
\hline Days to pay & 5.60 & 4.53 & 1.00 & 30.00 & 5.00 & 106 \\
\hline$\%$ Traders pay different price & 11 & & & & & 115 \\
\hline$\%$ Credit premium & 25.00 & & & & & 13 \\
\hline \multicolumn{7}{|l|}{ Credit to clients } \\
\hline Days to pay & 10.97 & 11.32 & 1.00 & 60.00 & 7.00 & 423 \\
\hline$\%$ Traders pay different price & 14 & & & & & 511 \\
\hline$\%$ Credit premium & 12.28 & & & & & 73 \\
\hline \multicolumn{7}{|l|}{ Advances to farmers } \\
\hline Days to pay & 14.38 & 22.22 & 1.00 & 90.00 & 5.00 & 52 \\
\hline$\%$ Traders pay different price & 0.24 & 0.43 & 0.00 & 1.00 & 0.00 & 67 \\
\hline \multicolumn{7}{|l|}{ Determination of price } \\
\hline$\%$ market price at delivery & 19 & & & & & 69 \\
\hline$\%$ price set forward & 75 & & & & & 69 \\
\hline$\%$ Advance discount & 0.00 & & & & & \\
\hline
\end{tabular}

Credit duration is a bit longer than with traders -- 14 days on average with a median of 7 days-but it is certainly shorter than the agricultural season. Surveyed traders therefore are not in the business of financing agricultural production. Advances to farmers appear like a way for traders to secure sufficient quantities and plan their activities from one week to another. 


\subsection{Use of Intermediaries}

Intermediaries—brokers, buying agents, consignment agents—are a substitute for networks: instead of knowing lots of potential buyers, a trader might choose to know a single agent who sells to all of them. To investigate these issues, data were collected on the use of intermediaries. Results indicate that intermediaries are much more frequently used in Benin than in Malawi: 31\% of Benin traders use buying agents; $26 \%$ use consignment agents. The corresponding numbers are $6 \%$ and $0 \%$ in Malawi. The only category of intermediaries where the two countries are more or less similar is brokers: $8 \%$ of Benin traders use them, vs. $3 \%$ of Malawian traders. Some $70 \%$ of Benin traders also use an intermediate category called 'apprentice'. Although not strictly speaking agents, apprentices straddle across the employee and agent category. In practice they are encouraged to use their initiative and are used as selling agents. In two third of the cases, apprentices are close relatives. On average Benin traders deal with 2 such apprentices.

Similar figures arise if we focus on the last purchase only. We find that $31 \%$ of Benin traders used an agent to purchase agricultural products vs. only $3 \%$ of Malawian respondents. On the selling side, $27 \%$ of Benin traders used an agent vs. $3 \%$ in Malawi. In Benin, the selling agent is half the time a broker, half the time an apprentice.

The total number of agents used also varies significantly across the two countries, with a much larger number of agents - especially buying agents and apprentices (selling agents) -- used in Benin and a longer period of acquaintance -- 2.2 years for buying agents in Benin vs. 1 month in Malawi. Malawian agents are portrayed as rather similar to the respondent in terms of origin, ethnicity, and religion. Social interaction outside business is also more likely than in Benin, and agent are more likely to be close relatives and to operate exclusively for the respondent. In contrast, Benin agents appear to be as different from the respondent as are regular clients and suppliers.

From this information, we conclude that the use of intermediaries is much more prevalent in Benin and that agents are more easily trusted. In contrast, Malawian respondents deal with few agents and do so only sporadically. When they do, the agent is someone they can identify with more easily than with the general trader population. 
Table 17. Traders' Use of Intermediaries in Benin and Malawi

\begin{tabular}{|c|c|c|c|c|c|c|}
\hline & \multicolumn{3}{|c|}{ Benin } & \multicolumn{3}{|c|}{ Malawi } \\
\hline & $\begin{array}{r}\text { Buying } \\
\text { agent }\end{array}$ & Broker & $\begin{array}{r}\text { Consign. } \\
\text { agent }\end{array}$ & $\begin{array}{r}\text { Buying } \\
\text { agent }\end{array}$ & Broker & $\begin{array}{r}\text { Consign. } \\
\text { agent }\end{array}$ \\
\hline$\%$ Traders with at least one agent & $31 \%$ & $8 \%$ & $26 \%$ & $6 \%$ & $3 \%$ & $0 \%$ \\
\hline Average number of agents & 1.79 & 0.29 & 0.37 & 0.17 & 0.09 & 0.01 \\
\hline Average years worked together & 2.22 & 0.49 & 2.23 & 0.15 & 0.05 & 0.01 \\
\hline \multicolumn{7}{|l|}{$\%$ Traders with agents: } \\
\hline Of same origin & $85 \%$ & $85 \%$ & $78 \%$ & $96 \%$ & $100 \%$ & $100 \%$ \\
\hline Of same ethnic group & $42 \%$ & $41 \%$ & $36 \%$ & $76 \%$ & $69 \%$ & $100 \%$ \\
\hline Of same religion & $37 \%$ & $36 \%$ & $43 \%$ & $60 \%$ & $40 \%$ & $100 \%$ \\
\hline With whom meet socially & $27 \%$ & $44 \%$ & $35 \%$ & $43 \%$ & $34 \%$ & $43 \%$ \\
\hline Who are close relatives & $7 \%$ & $6 \%$ & $4 \%$ & $20 \%$ & $9 \%$ & $14 \%$ \\
\hline Who are exclusive agents & $23 \%$ & $13 \%$ & $13 \%$ & $56 \%$ & $22 \%$ & $100 \%$ \\
\hline
\end{tabular}

\subsection{Information gathering and search}

Next we examine how traders collect information about prices and market conditions and search for suppliers and clients. The average agricultural trader follows (a little over) two agricultural products regularly. He or she also follows regularly two supply markets and (a little over) one sales market. This is consistent with the observed pattern by which most surveyed traders are located in their sales market and source their products from a small number of nearly supply markets.

Surveyed traders regularly consult an average of 3 people in Benin -- 7 people in Malawi-to collect information about prices. More people are consulted on the trader's main market (which is typically a sales market) than on other markets (which are typically supply sources). This is probably because the trader spends more time on his main sales market. Tracking the ongoing selling price closely is essential to get the highest possible margin without losing customers. An average of (a little over) one worker participate to the collection of price information, which imply that most employees of the trading enterprise are involved in one way or another in closely monitoring prices. In $54 \%$ of cases, Benin traders estimate that so doing they are able to collect reliable information about ongoing prices on supply markets without having to visit them; $78 \%$ of Malawian traders make the same claim. 
We asked respondents to report the main source of information on prices in their main market and other markets. Talking to other traders is by far the major source of information on prices either in one's own market or on other markets: $64 \%$ of Benin traders and $84 \%$ of Malawian traders report conversations with other traders, including clients and suppliers, as their main source of information about prices in their home market. Surprisingly, intermediaries are hardly ever mentioned. Surveyed traders do not appear to rely on agents to quote reliable prices. In Malawi, 7\% of respondents respond that they do not need to collect information because they set their own price.

Regarding other markets, talking to other traders is again the main source of information. Suppliers are reported as a major source of information by one third of Malawian traders. This is a priori surprising since suppliers have an incentive to overestimate the price. The radio is cited as a main source of information by $8 \%$ of Malawian traders. One quarter of Benin traders and ten percent of Malawian traders rely on personal observation - which means that they physically visit the market, eavesdrop, and act as a potential customer to get price quotes.

Keeping in touch with other markets, however, takes a bit more effort than just talking with a few traders. One important factor in this state of affairs is the extremely low usage of telephones: agricultural traders place, on average, 4 to 8 business-related calls a year. This is an extremely low frequency that is likely to change as cellular phones become more widely available in Africa.

Personal visits to other purchase and sales markets make up for lack of telephone. Surveyed traders make an average of 250 trips a year to purchase and sales markets in Benin and 92 trips a year in Malawi. The corresponding medians are 133 (Benin) and 52 (Malawi). In Benin, most trips are to sales market; in Malawi, three quarters of the trips are to supply markets. As mentioned earlier, the cumulated annual cost of these trips is not negligible and it represents a major cost for traders.

The high frequency of travel means that traders are absent quite often from their main market. Given that they do not use telephones, they cannot easily keep in touch with conditions in their main market while they are away. The need to travel frequently to supply markets probably explains why traders source products primarily from nearby markets. 
Table 18. $\quad$ Search Behavior of Traders in Benin and Malawi

\begin{tabular}{|c|c|c|c|c|c|c|}
\hline & \multicolumn{2}{|c|}{ Benin } & \multicolumn{4}{|c|}{ Malawi } \\
\hline & Mean & S.d. & $\mathrm{N}$ & Mean & S.d. & $\mathrm{N}$ \\
\hline \multicolumn{7}{|l|}{ Information collection } \\
\hline Number of products followed & 2.3 & 1.6 & 662 & 2.1 & 1.1 & 738 \\
\hline Number of supply markets followed & 2.0 & 1.7 & 662 & 2.1 & 1.2 & 738 \\
\hline Number of sales markets followed & 1.2 & 0.5 & 660 & 1.3 & 0.8 & 738 \\
\hline Number of people consulted in own market & 1.8 & 1.6 & 651 & 5.3 & 6.2 & 737 \\
\hline Number of people consulted in other markets & 1.5 & 2.0 & 647 & 2.0 & 3.1 & 737 \\
\hline $\begin{array}{l}\text { Number of employees who collect price } \\
\text { information }\end{array}$ & 1.1 & 2.1 & 656 & 1.2 & 0.9 & 733 \\
\hline $\begin{array}{l}\% \text { Traders who obtain reliable information } \\
\text { without visit }\end{array}$ & $54 \%$ & 0 & 502 & $78 \%$ & 0 & 593 \\
\hline \multicolumn{7}{|l|}{ Cost of search } \\
\hline Number of phone calls per year & 4 & 32 & 606 & 8 & 76 & 685 \\
\hline Number of trips to purchase markets per yr. & 107 & 439 & 642 & 74 & 133 & 710 \\
\hline Cost of trips to purchase markets $(\$ / y r)$ & 297 & 1421 & 537 & 443 & 1348 & 564 \\
\hline Number of trips to sales market per year & 145 & 698 & 627 & 25 & 75 & 623 \\
\hline Cost of trips to sales markets $(\$ / y r)$ & 177 & 805 & 414 & 1219 & 4843 & 219 \\
\hline
\end{tabular}

\subsection{Contractual performance}

Respondents were asked to report the number of cases of contract non-performance they encountered in the year preceding the survey. Results indicate a much higher incidence of contractual nonperformance in Malawi than in Benin. In Benin, traders only report a handful of cases of bad quality, disagreement over measures, or ex post price renegotiation with suppliers. In contrast, Malawian traders report close to 200 such occurrences per year-roughly $6 \%$ of purchases. Because Malawian traders are more likely to place orders with suppliers, they are also more likely to encounter late or non-delivery problems. In fact, the probability of non-performance appears to be quite high on orders. Given that the placement of orders is more likely when the market is tight, this is hardly surprising. But it serves as a reminder that surveyed traders do not conceive contracts as binding.

The two countries are more similar on the selling side, although the frequency of payment problems is about twice as high in Malawi than in Benin. Malawian traders are also much more likely to mention efforts by clients to renegotiate prices ex post. The frequency of payment problems is very low in both countries - of the order of 0.5 to $0.6 \%$. Surveyed traders have on average one person in the firm dealing with 
debt collection. The fear to lose one's reputation might be a deterrent to non-payment: $53 \%$ of Benin traders and $70 \%$ of Malawian traders state that other suppliers would get to know if a client would not pay the respondent.

Table 19. Contract Enforcement and Commercial Disputes in Benin and Malawi

\begin{tabular}{|c|c|c|c|c|c|c|}
\hline & \multicolumn{3}{|c|}{ Benin } & \multicolumn{3}{|c|}{ Malawi } \\
\hline & Mean & S.d. & $\mathrm{N}$ & Mean & S.d. & $\mathrm{N}$ \\
\hline \multicolumn{7}{|l|}{ Problems with suppliers (\% of traders): } \\
\hline Bad quality & $3 \%$ & & 663 & $41 \%$ & & 736 \\
\hline Disagreement over measuring & $7 \%$ & & 663 & $35 \%$ & & 733 \\
\hline Renegotiate price & $12 \%$ & & 662 & $25 \%$ & & 731 \\
\hline Cases of bad quality per year & 0.3 & 2.8 & 663 & 63.9 & 340.9 & 736 \\
\hline Cases of measuring dispute per year & 2.3 & 12.4 & 662 & 99.5 & 410.9 & 733 \\
\hline Cases of price renegotiation per year & 1.6 & 6.0 & 657 & 45.7 & 217.5 & 731 \\
\hline \multicolumn{7}{|l|}{ Orders with Suppliers } \\
\hline$\%$ Traders who place orders & $6 \%$ & & 658 & $32 \%$ & & 735 \\
\hline$\%$ Total purchases on order & 1.2 & 6.4 & 655 & 6.3 & 12.7 & 733 \\
\hline Number suppliers from whom order & 0.0 & 0.4 & 656 & 0.7 & 3.9 & 732 \\
\hline$\%$ Traders with late delivery problems & $18 \%$ & & 50 & $41 \%$ & & 296 \\
\hline$\%$ Traders with problems of partial delivery & $20 \%$ & & 50 & $31 \%$ & & 296 \\
\hline$\%$ Traders with problems of no delivery & $16 \%$ & & 50 & $27 \%$ & & 295 \\
\hline Cases of late delivery per year & 5.0 & 20.8 & 50 & 37.5 & 197.5 & 296 \\
\hline Cases of partial delivery per year & 3.1 & 9.3 & 50 & 19.0 & 57.7 & 296 \\
\hline Cases of no delivery per year & 0.3 & 0.8 & 50 & 31.3 & 148.0 & 294 \\
\hline \multicolumn{7}{|l|}{ Problems with clients (\% of traders): } \\
\hline Late payment & $24 \%$ & & 660 & $42 \%$ & & 734 \\
\hline Partial payment & $21 \%$ & & 660 & $34 \%$ & & 733 \\
\hline No payment & $20 \%$ & & 660 & $25 \%$ & & 733 \\
\hline Renegotiate price & $5 \%$ & & 658 & $20 \%$ & & 731 \\
\hline Cases of late payment per year & 10.8 & 34.1 & 656 & 15.2 & 36.5 & 734 \\
\hline Cases of partial payment per year & 9.8 & 62.2 & 656 & 14.9 & 71.8 & 733 \\
\hline Cases of no payment per year & 0.9 & 3.4 & 659 & 7.1 & 62.4 & 732 \\
\hline Cases of price renegotiation per year & 0.4 & 2.1 & 655 & 116.0 & 506.7 & 730 \\
\hline Number clients who order & 0.1 & 0.6 & 662 & 0.5 & 1.6 & 722 \\
\hline Number of sales & 3102 & 4433 & 198 & 7898 & 9140 & 734 \\
\hline $\begin{array}{l}\% \text { Traders for whom others will find out if } \\
\text { they encounter non payment problems }\end{array}$ & $53 \%$ & & 619 & $70 \%$ & & 734 \\
\hline $\begin{array}{l}\text { Number of employees dealing with debt } \\
\text { collection }\end{array}$ & 1.1 & 1.0 & 641 & 0.7 & 0.6 & 682 \\
\hline
\end{tabular}




\subsection{Protection of property}

We end this section with a short description of how surveyed traders protect their property. In the year preceding the survey, $16 \%$ of Benin traders and $33 \%$ of Malawian traders were victims of theft. This is higher than the incidence of theft reported in Fafchamps and Minten (2001b) for Madagascar. The value of stolen property was fairly low, however: \$22 per year on average. Some traders, however, incurred much higher losses - of the order of $\$ 2500$ in each country.

Few respondents directly blame employees for the thefts, but only $62 \%$ of Benin traders are confident that employees were not involved ( $72 \%$ in Malawi). Contrary to what Fafchamps and Minten (2001b) report for Madagascar, fear of pilferage does not discourage traders from hiring employees: only $3 \%$ of Benin respondents and $11 \%$ of Malawian respondents state they refrain from hiring additional employees for fear of theft.

The methods most commonly used to protect one's property are to lock it at night $(75 \%$ of those who store in Benin, $87 \%$ in Malawi), hire a guard (40\% and $28 \%$ respectively) and sleep on the premises (19\% and $48 \%$ respectively). For those who transport, some protection is occasionally sought as well: some traders travel in convoy (10\% in Benin, $19 \%$ in Malawi); some avoid particular routes ( $8 \%$ in Benin, $17 \%$ in Malawi); and some hire guards during transport (4\% and 17\%). Protection during transport thus appears slightly more problematic in Malawi, possibly because the country is less densely populated and ambush is easier to organize. 
Table 20. Methods of Protecting Commercial Property in Benin and Malawi

\begin{tabular}{|c|c|c|c|c|c|c|}
\hline & \multicolumn{3}{|c|}{ Benin } & \multicolumn{3}{|c|}{ Malawi } \\
\hline & Mean & S.d. & $\mathrm{N}$ & Mean & S.d. & $\bar{N}$ \\
\hline \multicolumn{7}{|l|}{ Incidence of Theft } \\
\hline Victim of theft & $16 \%$ & & 662 & $33 \%$ & & 730 \\
\hline Employees involved in theft & $5 \%$ & & & $9 \%$ & & \\
\hline Value of stolen property (\%of sales) & 0.59 & 4.50 & 627 & 0.28 & 1.83 & 683 \\
\hline \multicolumn{7}{|l|}{ Methods to Protect Property (\% Traders) } \\
\hline Avoid hiring employees & $3 \%$ & & 660 & $11 \%$ & & 735 \\
\hline Goods kept under lock & $65 \%$ & & 639 & $82 \%$ & & 735 \\
\hline Guard on premises & $34 \%$ & & 639 & $26 \%$ & & 735 \\
\hline Sleep on premises & $15 \%$ & & 639 & $45 \%$ & & 735 \\
\hline Travel in convoy & $8 \%$ & & 639 & $13 \%$ & & 735 \\
\hline Avoid certain routes & $7 \%$ & & 639 & $13 \%$ & & 735 \\
\hline Hire guard during tranport & $3 \%$ & & 639 & $12 \%$ & & 735 \\
\hline
\end{tabular}

\section{Commercial Activities}

In the following two sections, we compare commercial activities and market performance of traders across categories, or terciles, of firm assets — namely working capital, human capital, and social capital — as well as gender. We begin with a brief discussion of the asset categories. In the case of working capital, we noted earlier that working capital held by individual traders was extremely skewed in both countries, particularly in Benin, where working capital ranges from $\$ 0$ to $\$ 217,000$, and less so in Malawi, where it ranges from $\$ 0$ to $\$ 34,100$. Thus, in Benin, the bottom tercile has up to $\$ 167$ in working capital, while the second tercile has between $\$ 167$ and $\$ 667$ in working capital. The top tercile of working capital has a very broad range, from $\$ 667$ to the maximum, $\$ 217,000$, working capital. In contrast, traders' working capital appears to be more widely distributed in Malawi. Thus, the bottom tercile has up to $\$ 1900$ in working capital, while the middle tercile has a range between $\$ 1900$ and $\$ 11,300$. The top third has a range from $\$ 11,300$ to $\$ 34,100$.

Unlike working capital, the amount of human resources employed by traders does not vary significantly within the sample. In both countries, the majority of trading firms employ one employee (44\% 
of the sample in Benin and $72 \%$ in Malawi), suggesting that trading firms remain micro-enterprises. In the top third of firms in Benin, the number of employees varies from 2 to 14, with the exception of 4 firms with a greater number of employees (up to a maximum of 67 employees). In Malawi, only $11 \%$ of firms have more than 2 employees, up to a maximum of 22 employees.

In terms of social capital, defined as the number of trading contacts known by each respondent, traders in both countries have quite similar patterns. The $66^{\text {th }}$ percentile is 33 and 36 contacts in Benin and Malawi, respectively. The top third has a considerably broader range, up to 530 contacts in Benin and 244 contacts in Malawi.

\subsection{Annual Sales}

Overall, median sales do not differ much across the two countries, with the median trader selling $\$ 5,300$ to $\$ 6,700$ worth of merchandise per year. These differences across countries mask dramatic variation in volume of activity within each country: the Gini coefficient of the total value of annual sales is 0.60 in Benin and 0.38 in Malawi. In both countries, the largest surveyed trader had sales of 2.6 to 2.8 million dollars a year while $17 \%$ of the sample sold less than $\$ 1000$ of merchandise in a year. Viewing median sales activity by working capital terciles reveals that the top tercile of traders have 11-13 times more sales than the bottom tercile and 4-5 times more than the middle tercile in both countries.

In sharp contrast, human resources do not appear to have as important returns in terms of sales activity in Benin. Median sales in the top human resource tercile are just 4 times higher than the bottom tercile and slightly more than twice as high as the middle tercile. In Malawi, where $72 \%$ of firms have 1 employee, firms with more than 1 employee have 4-5 times higher median sales. A similar pattern also exists for social capital in both countries, where the top tercile only has 2-3 times more sales than the bottom terciles. These findings suggest that working capital is a more determinant factor in traders' activities than either human or social capital. 
Finally, gender appears to have a significant impact on sales activity, such that male traders, who represent only $20 \%$ of the sample in Benin, have median sales less than 4 times that of female traders and nearly 3 times higher in Malawi, where female traders represent $35 \%$ of the sample.

Table 21. Value of Annual Sales (US\$) by Firm Assets in Benin and Malawi ${ }^{A}$

\begin{tabular}{|c|c|c|c|c|c|c|c|c|c|}
\hline & & Benin & & & & & Malawi & & \\
\hline Working Capital & Mean & S.d. & Median & $\mathrm{N}$ & Working Capital & Mean & S.d. & Median & $\mathrm{N}$ \\
\hline$<\$ 167$ & 6730.17 & 33769.20 & 1256.20 & 156 & $<\$ 78$ & 4587.98 & 10152.16 & 2189.39 & 193 \\
\hline$\$ 167-\$ 667$ & 11584.85 & 22628.95 & 3315.41 & 226 & $\$ 78-\$ 244$ & 9324.91 & 13745.82 & 5762.43 & 201 \\
\hline$>=\$ 667$ & 49678.56 & 192965.70 & 16227.29 & 201 & $>=\$ 244$ & 111471.30 & 292941.00 & 25222.22 & 204 \\
\hline Human Capital & & & & & Human Capital & & & & \\
\hline$<=1$ employee & 20553.89 & 148507.28 & 2743.84 & 324 & 0 - 1 employee & 13227.18 & 43077.18 & 4584.099 & 427 \\
\hline 1 - 2 employees & 16250.84 & 26356.02 & 4942.71 & 138 & $>1$ employee & 120549.4 & 321935.10 & 20373.28 & 163 \\
\hline$>2$ employees & 36126.53 & 72551.90 & 12296.52 & 137 & & & & & \\
\hline Social Capital & & & & & Social Capital & & & & \\
\hline$<10$ & 7648.122 & 12362.21 & 2402.91 & 165 & $<15$ & 23437.30 & 85306.21 & 3830.24 & 185 \\
\hline $10-33$ & 26843.05 & 174167.70 & 4370.39 & 234 & $15-36$ & 56147.91 & 243645.00 & 6556.48 & 213 \\
\hline$>=33$ & 30734.48 & 63358.51 & 9800.92 & 205 & $>=36$ & 46022.60 & 157136.00 & 8773.51 & 200 \\
\hline Gender & & & & & Gender & & & & \\
\hline Male & 38804.14 & 73557.73 & 14402.37 & 120 & Male & 57823.06 & 214243.50 & 8781.95 & 387 \\
\hline Female & 18983.95 & 122557.00 & 3724.44 & 486 & Female & 14798.12 & 68196.87 & 3177.16 & 211 \\
\hline Total & 22908.74 & 114750.80 & 5366.64 & 606 & Total & 42642.02 & 178148.70 & 6579.04 & 598 \\
\hline
\end{tabular}

a US $\$$ equivalent. At the time of survey, exchange rates used are 1 US $\$=$ CFA 600 and 1 US $\$=$ MK 45.

\subsection{Transport: Arbitrage over Space}

Transport Practices and Rates. One fifth of surveyed traders do not undertake any transport, by which they mean that they buy and sell from the same market. The others transport products across markets, nearly always with an external transporter.

Most transport (86\%) takes place in trucks. Half of these trucks are small pick-ups. Some $13 \%$ of all transport takes place with non-motorized means of transport such as handcarts and oxcarts. Respondent traders in either of the countries studied do not use train transport. Measured in dollars per ton per km, transport costs average $\$ 0.43$ and $\$ 0.70$ in Benin and Malawi, respectively. Transport charges vary 
dramatically by mode of transport, however. Non-motorized transport costs on average $\$ 1.78$ (Benin) and $\$ 1.20$ (Malawi). In contrast, motorized transport costs $\$ 0.28$ and $\$ 0.63$ in Benin and Malawi, respectively. Regressing transport costs on distance and means of transport indicates that truck transportation has a higher fixed cost but lower cost per $\mathrm{km}$. Consistent with expectations, we find that small trucks are significantly more expensive than large trucks, but the difference is not large. Non-motorized transport is use primarily on short distances -- $4 \mathrm{~km}$ on average in Benin, $12 \mathrm{~km}$ in Malawi. Large trucks are used primarily on long distances -- $120 \mathrm{~km}$ in Malawi, $160 \mathrm{~km}$ in Benin. Pick-up trucks are used on medium distances, e.g., 40 to $70 \mathrm{~km}$.

Taken together, these features suggest that transport follows some economic rationale. The quantitative importance of short hauls, small trucks, and non-motorized transport probably contribute to high marketing costs. Comparing between Benin and Malawi, transported distances appear slightly higher in Benin, and transport rates per ton are lower, varying between $\$ 11 /$ ton to $\$ 14 /$ ton in Benin, compared to $\$ 16$ to $\$ 20 /$ ton in Malawi. Further indication that the transport sector is more competitive in Benin is that the variation between the peak transport rate in the marketing year along selected routes and the prevailing rate at the time of the survey is lower in Benin, with an 3-11\% increase in the peak season compared to a $16-$ $18 \%$ increase in Malawi. These figures suggest that there may less congestion in the transport system in Benin, while transport may be more of a constraint in the peak transport period in Malawi. 
Table 22. Transport Practices and Means

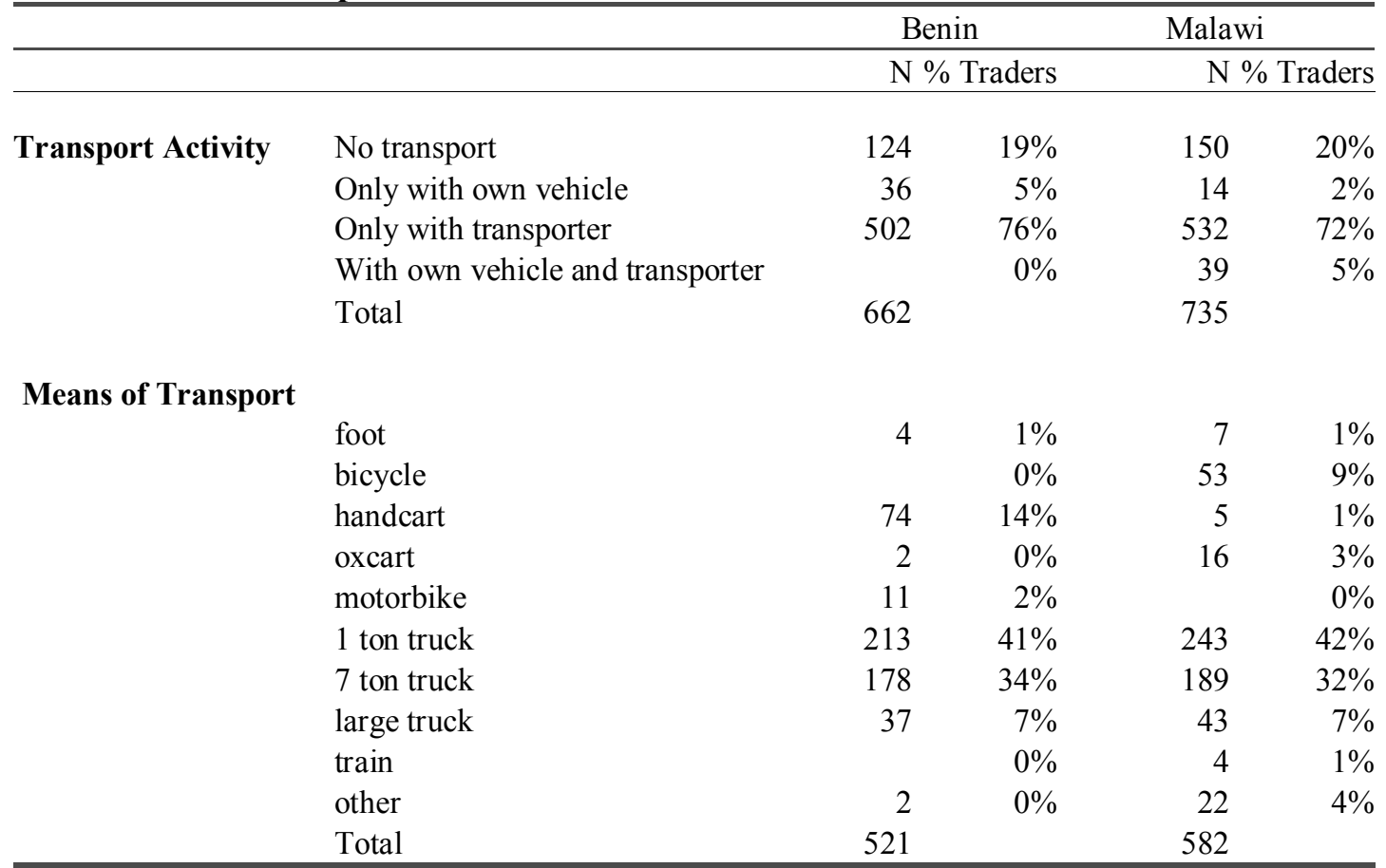

Table 23. Transported Distances and Rates on Selected Routes

\begin{tabular}{|c|c|c|c|c|c|c|}
\hline & \multicolumn{6}{|c|}{ Benin } \\
\hline & \multicolumn{2}{|c|}{ Kilometers } & \multicolumn{2}{|c|}{$\$ / \operatorname{ton}^{\mathrm{a}}$} & Peak rate ratio & $\mathrm{N}$ \\
\hline & Mean & S.d. & Mean & S.d. & & \\
\hline Route 1 & 64.05 & 114.67 & 11.23 & 9.82 & 1.11 & 504 \\
\hline Route 2 & 40.74 & 95.96 & 13.65 & 12.73 & 1.11 & 275 \\
\hline \multirow[t]{4}{*}{ Route 3} & 17.08 & 64.73 & 12.15 & 7.82 & 1.03 & 119 \\
\hline & \multicolumn{6}{|c|}{ Malawi } \\
\hline & \multicolumn{2}{|c|}{ Kilometers } & \multicolumn{2}{|c|}{$\$ /$ ton $^{\mathrm{a}}$} & Peak rate ratio & $\mathrm{N}$ \\
\hline & Mean & S.d. & Mean & S.d. & & \\
\hline Route 1 & 55.27 & 80.20 & 16.04 & 15.62 & 1.18 & 563 \\
\hline Route 2 & 34.95 & 69.71 & 19.91 & 28.62 & 1.16 & 337 \\
\hline Route 3 & 13.10 & 50.64 & 20.06 & 41.25 & 1.17 & 122 \\
\hline
\end{tabular}

a At the time of survey, exchange rates used are 1 US $\$=$ CFA 600 and 1 US $\$=$ MK 45. 
Transport in the Last Transaction. Information was collected on the last completed transaction undertaken by respondents. A 'transaction' is essentially a purchase of goods that is assembled by the trader in the supply market, transported to the sales market, and sold over a period of time. The average distance between the purchase and sale market varies between $53 \mathrm{~km}$ in Malawi and $69 \mathrm{~km}$ in Benin. Median distances are much shorter, however -- $15 \mathrm{~km}$ in Malawi and $23 \mathrm{~km}$ in Benin. This means that most agricultural traders only travel very short distances to their supply market.

Viewed by firms, traders in the lowest working capital terciles in both countries are typically retailers who do not engage in any transport. However, the analysis of the middle and top terciles of working capital, human resources, and social capital reveals that firm assets do not appear to greatly influence the distances traded. Similarly, while male traders do generally trade across greater distances in both countries, the median distances are not widely divergent between the two groups.

Table 24. Transported Distance (kms) on Last Transaction by Firm Assets

\begin{tabular}{|c|c|c|c|c|c|c|c|c|c|}
\hline \multicolumn{6}{|c|}{ Benin } & \multicolumn{4}{|c|}{ Malawi } \\
\hline & Mean & S.d. & Median & $\mathrm{N}$ & & Mean & S.d. & Median & $\bar{N}$ \\
\hline \multicolumn{10}{|l|}{ Working Capital } \\
\hline$<\$ 167$ & 22.51 & 67.19 & 0.00 & 170 & $<\$ 78$ & 28.22 & 46.65 & 0.00 & 230 \\
\hline$\$ 167-\$ 667$ & 55.61 & 80.55 & 25.00 & 229 & $\$ 78-\$ 244$ & 61.67 & 95.06 & 21.50 & 208 \\
\hline$>=\$ 667$ & 130.46 & 260.53 & 51.50 & 192 & $>=\$ 244$ & 73.09 & 95.87 & 45.00 & 204 \\
\hline \multicolumn{10}{|l|}{ Human Capital } \\
\hline$<=1$ employee & 41.39 & 83.20 & 11.50 & 342 & 0-1 employee & 52.37 & 86.95 & 10.00 & 468 \\
\hline $1-2$ employees & 93.90 & 285.35 & 35.50 & 130 & $>1$ employee & 54.97 & 69.92 & 30.00 & 166 \\
\hline$>2$ employees & 108.21 & 141.96 & 53.00 & 135 & & & & & \\
\hline \multicolumn{10}{|l|}{ Social Capital } \\
\hline$<10$ & 29.40 & 60.62 & 11.00 & 185 & $<15$ & 45.32 & 76.73 & 2.00 & 205 \\
\hline $10-33$ & 59.36 & 213.74 & 12.00 & 227 & $15-36$ & 53.15 & 91.64 & 14.00 & 226 \\
\hline$>=33$ & 115.05 & 152.75 & 53.00 & 200 & $>=36$ & 61.26 & 80.37 & 40.00 & 211 \\
\hline \multicolumn{10}{|l|}{ Gender } \\
\hline Male & 110.32 & 146.89 & 52.00 & 121 & Male & 56.03 & 83.63 & 20.00 & 397 \\
\hline Female & 58.72 & 166.32 & 18.00 & 493 & Female & 48.92 & 83.39 & 10.00 & 245 \\
\hline Total & 68.89 & 163.85 & 23.00 & 614 & Total & 53.31 & 83.54 & 15.00 & 642 \\
\hline
\end{tabular}




\subsection{Storage: Arbitrage over Time}

Most surveyed traders do not stock products. They typically purchase a load and hold onto it until it is sold, after which they visit their sale market to replenish their stock. Contrary to common beliefs, the great majority of traders do not undertake speculative or seasonal storage. The average stock held is a tiny fraction of annual sales -- of the order of $1 \%$ on average.

There is, however, a small minority of traders who are involved in arbitrage across time. Some $10 \%$ of traders hold stocks for over a month. To estimate returns to storage, we regressed the logarithm of the ratio of selling price over buying price on time and crop specific dummies. This yields an estimate of the increase in gross margin associated with storage. Results suggest that the return to an additional day of storage is $0.25 \%$ in Malawi and $0.05 \%$ in Benin. These figures, compounded on a daily basis to keep up with the estimation method, are equivalent to a return rate of $25 \%$ (Malawi) and $4 \%$ (Benin) on 90 day storage $^{1}$. These results indicate that average returns to storage are not as large as often reported in the popular press, which is probably why so few traders bother to stock over long periods. Storage is also a very risky activity since realized returns can vary widely around these expected returns. Larger returns can probably be achieved by rotating one's working capital faster instead of immobilizing it in idle stocks.

1 Similar results are obtained with a linear specification. A median regression also yield similar results. The contrast between the two countries may be due to the fact that Benin has two rainy seasons. Consequently, the supply of food is more evenly distributed over the entire year. 
Table 25. $\quad$ Storage Practices

\begin{tabular}{|c|c|c|c|c|c|c|}
\hline & \multicolumn{3}{|c|}{ Benin } & \multicolumn{2}{|c|}{ Malawi } & \multirow[b]{2}{*}{$\bar{N}$} \\
\hline & Mean & S.d. & $\mathrm{N}$ & Mean & S.d. & \\
\hline$\%$ Traders that trade at residence & $59 \%$ & & 661 & $35 \%$ & & 738 \\
\hline$\%$ Traders that store at residence & $47 \%$ & & 659 & $54 \%$ & & 737 \\
\hline Storage capacity at residence (kgs) & 3836 & 10497 & 658 & 5790 & 35873 & 733 \\
\hline$\%$ Traders that Store outside home & $24 \%$ & & 649 & $39 \%$ & & 736 \\
\hline Storage capacity outside of residence (kgs) & 3253 & 9715 & 649 & 6233 & 38269 & 728 \\
\hline$\%$ Traders with Access to collective storage & $57 \%$ & & 658 & $32 \%$ & & 735 \\
\hline Cost of collective storage & 0.26 & 0.28 & 139 & 3.12 & 8.11 & 153 \\
\hline$\%$ Traders that own residence & $24 \%$ & & 660 & $75 \%$ & & 738 \\
\hline Value of residence & 13689 & 43283 & 141 & 1039 & 3223 & 554 \\
\hline$\%$ Traders that owned residence a year ago & $98 \%$ & & 155 & $96 \%$ & & 560 \\
\hline
\end{tabular}

Not all quantities purchased had been sold by the time of the survey. On average, surveyed traders had sold 85 to $90 \%$ of the quantities purchased by the time of the interview and had, on average, recouped the value of the purchased goods. The number of days elapsed since the last purchase varied significantly between the two countries, however: 22 days on average in Benin vs. 8 in Malawi ( $\mathrm{t}$ value of 9.6). Medians were sizably lower -- 8 and 3 days respectively. Ninety percent of surveyed traders keep goods for less than a month. This suggests that storage is concentrated in the hands of a few traders. The majority of traders keep the products for a short period only, typically the time it takes to sell the batch of purchased goods.

A comparison of storage behavior across the various categories of assets reveals that there is little variation among asset groups. Indeed, in the case of human resources and social capital in Benin, traders in the lowest terciles have the highest days of storage. A possible explanation for this may be that the less endowed traders are typically retailers, whose main business is transforming the good from a larger lot size to smaller transaction units (eg., from $100 \mathrm{~kg}$ bags to under $1 \mathrm{~kg}$ traditional units). Thus, these traders require a longer period of time to complete a transaction according to the above definition, in which the total quantity purchased at one time is liquidated. 
Table 26. Storage Days on Last Transaction by Firm Assets

\begin{tabular}{|c|c|c|c|c|c|c|c|c|c|}
\hline \multicolumn{6}{|c|}{ Benin } & \multicolumn{4}{|c|}{ Malawi } \\
\hline & Mean & S.d. & Median & $\mathrm{N}$ & & Mean & S.d. & edian & $\mathrm{N}$ \\
\hline \multicolumn{10}{|l|}{ Working Capital } \\
\hline$<\$ 167$ & 17.36 & 28.85 & 7.00 & 169 & $<\$ 78$ & 3.54 & 4.90 & 2.00 & 245 \\
\hline$\$ 167-\$ 667$ & 23.64 & 41.10 & 8.00 & 242 & $\$ 78-\$ 244$ & 7.08 & 12.09 & 3.00 & 245 \\
\hline$>=\$ 667$ & 23.61 & 32.69 & 10.00 & 210 & $>=\$ 244$ & 13.29 & 21.69 & 6.00 & 246 \\
\hline \multicolumn{10}{|l|}{ Human Capital } \\
\hline$<=1$ employee & 24.43 & 40.32 & 8.00 & 349 & 0-1 employee & 6.40 & 13.79 & 2.00 & 523 \\
\hline 1 - 2 employees & 13.35 & 19.62 & 7.00 & 147 & $>1$ employee & 12.03 & 17.81 & 6.00 & 204 \\
\hline$>2$ employees & 23.25 & 31.46 & 10.00 & 140 & & & & & \\
\hline \multicolumn{10}{|l|}{ Social Capital } \\
\hline$<10$ & 29.97 & 33.00 & 20.00 & 179 & $<15$ & 6.84 & 14.31 & 2.00 & 219 \\
\hline $10-33$ & 17.79 & 34.96 & 7.00 & 242 & $15-36$ & 8.60 & 14.63 & 3.00 & 269 \\
\hline$>=33$ & 19.18 & 35.69 & 7.00 & 219 & $>=36$ & 8.30 & 16.38 & 3.00 & 248 \\
\hline \multicolumn{10}{|l|}{ Gender } \\
\hline Male & 26.98 & 41.89 & 7.00 & 121 & Male & 9.02 & 15.82 & 3.00 & 468 \\
\hline Female & 20.39 & 33.08 & 8.00 & 521 & Female & 6.15 & 13.73 & 2.00 & 268 \\
\hline Total & 21.63 & 34.97 & 8.00 & 642 & Total & 7.98 & 15.15 & 3.00 & 736 \\
\hline
\end{tabular}

\subsection{Arbitrage over Transaction Size}

Evidence from the last transaction reveals that, on average, the load is purchased from 5 different suppliers in Benin -- 15 in Malawi. The load is then sold to an average of 10 (Benin) to 50 (Malawi) different clients. In two third of the cases, the trader himself or herself traveled to the supply market or markets to oversee the purchase. In nearly all cases, the respondent supplies his or her own bags or containers at the time of purchase, i.e., agricultural products are transferred from the seller's to the buyer's bags.

The ratio of the number of clients to the number of suppliers indicates whether the trader is engaged in arbitrage across form: buying in large quantities from a few suppliers and selling in small quantities to a large number of buyers. The data reveal that traders in Malawi appear to be more engaged in transformation to retail quantities than traders in Benin. Viewed by asset category, traders with larger financial endowments carry out less arbitrage over transaction size than smaller traders. The same is true for traders with higher social capital. In terms of human capital, given that transforming goods from larger 
to smaller transaction sizes requires human resources and capital, it appears that the lowest tercile in Benin are less involved in this activity than the other terciles.

Table 27. Change in Transaction Size ${ }^{a}$ by Firm Assets

\begin{tabular}{|c|c|c|c|c|c|c|c|}
\hline \multicolumn{5}{|c|}{ Benin } & \multicolumn{3}{|c|}{ Malawi } \\
\hline Terciles & Mean & S.d. & $\mathrm{N}$ & Terciles & Mean & S.d.. & $\bar{N}$ \\
\hline \multicolumn{8}{|l|}{ Working capital } \\
\hline$<\$ 167$ & 8.03 & 9.51 & 72 & $<\$ 78$ & 25.62 & 34.90 & 245 \\
\hline$\$ 167-\$ 667$ & 4.10 & 7.63 & 113 & $\$ 78-\$ 244$ & 34.70 & 50.71 & 245 \\
\hline$>=\$ 667$ & 2.80 & 5.28 & 125 & $>=\$ 244$ & 15.82 & 47.33 & 244 \\
\hline \multicolumn{8}{|l|}{ Human resources } \\
\hline$<1$ employee & 1.93 & 2.66 & 36 & 0 - 1 employee & 28.03 & 43.52 & 523 \\
\hline 1 - 2 employees & 6.32 & 9.02 & 114 & $>1$ employee & 19.24 & 50.29 & 202 \\
\hline$>2$ employees & 3.90 & 6.92 & 162 & Total & 25.58 & 45.64 & 725 \\
\hline \multicolumn{8}{|l|}{ Social Capital } \\
\hline$<10$ & 2.91 & 3.61 & 75 & $<15$ & 18.32 & 33.12 & 219 \\
\hline $10-33$ & 6.01 & 8.85 & 116 & $15-36$ & 25.51 & 41.30 & 268 \\
\hline$>=33$ & 4.18 & 7.75 & 124 & $>=36$ & 31.54 & 56.94 & 247 \\
\hline \multicolumn{8}{|l|}{ Gender } \\
\hline Male & 4.02 & 8.77 & 70 & Male & 23.31 & 43.49 & 466 \\
\hline Female & 4.67 & 7.16 & 246 & Female & 29.02 & 48.47 & 268 \\
\hline Total & 4.53 & 7.53 & 316 & Total & 25.39 & 45.43 & 734 \\
\hline
\end{tabular}

${ }^{a}$ Ratio of number of clients to number of suppliers.

This can be explained in that the smallest trading firms may typically buy in retail quantities and sell in retail quantities. Finally, contrary to expectations, there appears to be relatively little distinction between male and female traders in this activity, suggesting that retail activity is not exclusive to women. 


\section{Market Performance}

\subsection{Margins}

Gross Margins. The gross margin - the difference between the value of sales and purchasesvaries significantly between the two countries: it is 2.4 times higher in Malawi than in Benin (t-value of 4.83). Median margins differ by the same order of magnitude. Since total sales do not differ markedly between the two countries, higher gross margins in Malawi must come from a larger difference between buying and selling price.

This is indeed the case: the ratio of selling price over buying price is 1.23 on average in Benin (median of 1.19) while it is 1.53 in Malawi (median of 1.40). In other words, the selling price is on average $23 \%$ above the buying price in Benin but $53 \%$ above in Malawi. This difference is quite significant, with a tvalue of 11.7. This difference constitutes prima facie evidence that agricultural trade is in general less efficient in Malawi.

Margins also vary dramatically across traders. Some respondents appear to be making massive losses while others make windfall profits. Part of this variation undoubtedly comes from measurement error-since respondents do not hold accounts, annual sales and purchases must be extrapolated on the basis of a few key indicators. But the variation also suggests that unit margins are extremely volatile. Regarding their last transaction, close to 3\% of surveyed traders report selling at or below the purchase price. At the other end of the spectrum, some traders report selling at close to 10 times the purchase price. 
Table 28. Annual Gross Margins in Benin and Malawi

\begin{tabular}{lrrrrrr}
\hline \multicolumn{7}{c}{ Benin } \\
\hline & Mean & S.d. & Min. & Max. & Median & N \\
\hline Gross margin ratio on annual sales & $22.10 \%$ & $12.33 \%$ & $-18.62 \%$ & $77.46 \%$ & $20.26 \%$ & 595 \\
Gross margin rate on last purchase & $23.30 \%$ & $23.72 \%$ & $-64.29 \%$ & $294.12 \%$ & $18.52 \%$ & 656 \\
Annual gross margin (\$) & 3123.13 & 6662.62 & -88.72 & 58721.07 & 814.46 & 595 \\
Annual sales (\$) & 22872.40 & 114659.57 & 15.14 & 2615833.30 & 5322.92 & 607 \\
Annual purchases (\$) & 18147.20 & 91508.16 & 11.51 & 2098750.00 & 4254.71 & 607 \\
Sale price/purchase price & 1.23 & 0.24 & 0.36 & 3.94 & 1.19 & 656
\end{tabular}

\begin{tabular}{lrrrrrr}
\hline \multicolumn{7}{c}{ Malawi } \\
\hline & Mean & S.d. & Min. & Max. & Median & N \\
\hline Gross margin ratio on annual sales & $48.06 \%$ & $35.26 \%$ & $6.30 \%$ & $204.62 \%$ & $38.67 \%$ & 588 \\
Gross margin rate on last purchase & $53.17 \%$ & $60.85 \%$ & $-87.43 \%$ & $840.00 \%$ & $39.53 \%$ & 663 \\
Annual gross margin (\$) & 7386.84 & 20452.87 & 51.85 & 251876.18 & 1732.29 & 588 \\
Annual sales (\$) & 43611.15 & 182197.49 & 63.64 & 2848665.40 & 6728.57 & 598 \\
Annual purchases (\$) & 32731.61 & 142789.69 & 35.45 & 2358541.20 & 4343.29 & 598 \\
Sale price/purchase price & 1.53 & 0.61 & 0.13 & 9.40 & 1.40 & 663 \\
\hline
\end{tabular}

a At the time of survey, exchange rates were 1 US $\$=$ CFA 600 and 1 US $\$=$ MK 45.

\subsection{Costs}

Variable marketing costs. Detailed information was collected on the various costs incurred in the process of assembling, transporting, and selling the last quantities purchased. In the remainder of this section, we refer to these costs as variable marketing costs because they vary with the amount purchased and the number of transactions processed by the trader over the year. Variable marketing costs represent $\$ 20$ per ton in Benin and $\$ 31$ in Malawi ( $\mathrm{t}$ value of 8.43 ). Corresponding medians are $\$ 16$ and $\$ 20$. This compares to a median purchase price of $\$ 145$ and $\$ 162$ per ton in Benin and Malawi, respectively. Thus, for the median trader, variable marketing costs represent $11 \%$ to $13 \%$ of the purchase price. 
Table 29. Variable Marketing Costs by Firm Assets (US\$) ${ }^{a}$

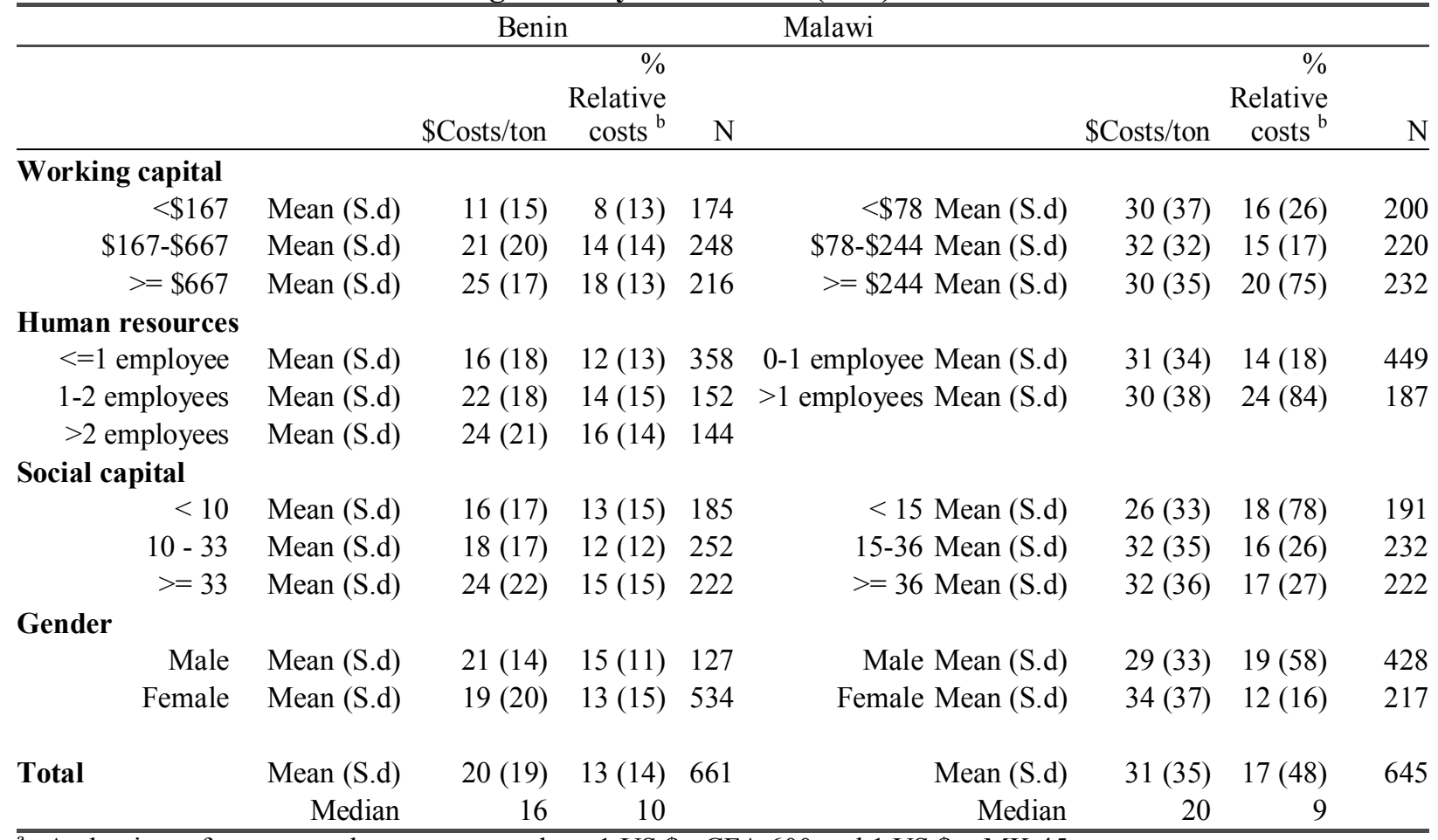

\footnotetext{
At the time of survey, exchange rates used are 1 US $\$=$ CFA 600 and 1 US $\$=$ MK 45.

${ }^{\mathrm{b}}$ Relative marketing costs are calculated as the ratio of marketing costs to purchase price.
}

In Benin, absolute marketing costs per ton increase with traders' assets, revealing that as the scale of operations rise, so too do the amount of services provided or commercial activities such as transport and storage. Similarly, relative marketing costs also rise with asset base, suggesting that more endowed traders are more competitive in that their net margins (holding the purchase price constant across terciles) will be lower, as will explored in the following section. Marketing costs generally appear higher in Malawi and it is less clear that costs rise with increased assets, particularly in relative terms. In both countries, as expected, male traders incur higher absolute and relative marketing costs.

Decomposition of Marketing Costs. We now turn to the decomposition of variable marketing costs. Respondents were asked to identify, for their last completed transaction, all the costs incurred between the purchase and the sale of the transacted goods. Thus, up to 19 types of costs were identified. For the purposes of analysis, these costs are classified into 10 categories: the cost of the empty sack, 
handling costs (the sum of bagging and sewing, loading at place of purchase, and off-loading at destination), the cost of transport itself, other transport-related costs such as payments at road stops and to transport brokers, storage costs (if paid per bag), the cost of telephone or radio communication related to the particular transaction, commissions paid to purchase and sales intermediaries and other tips, personal travel costs (if the trader accompanies the shipment), municipal and market taxes (if paid per bag or transaction), and other non-specific costs.

Transport represents by far the largest component of variable cost: $45 \%$ in Benin and $40 \%$ in Malawi. If we add other transport-related costs, we get a transport share of $49 \%$ in Benin. This confirms other empirical findings that transport represents the lion's share of marketing costs in sub-Saharan Africa (Badiane et al, 1997; Gabre-Madhin, 1991). The second most important variable cost component is the travel cost incurred by the trader. This cost can be interpreted as the cost of search for partners and information, since traders tend to accompany the shipment themselves rather than conducting sales and purchases by telephone or long-distance order. This cost alone represents $11 \%$ of total marketing costs in Benin and 23\% in Malawi. Together, transport of goods and of the trader represent the most significant share, $60 \%$ in Benin and $63 \%$ in Malawi, of the financial outlays associated with an individual transaction.

The cost of bags and of handling represents important categories of variable costs. The value of bags varies around $\$ 4$ to $\$ 6$ per ton. Bags are recycled and re-used an average of 5 (Benin) to 9 times (Malawi), which brings down bagging costs. The pro-rated cost of bags and the labor cost of bagging together account for $7 \%$ to $10 \%$ of total variable costs. This cost can also be viewed as directly related to the search for information. Traders indicate that re-sacking of the goods is customary at each transfer of ownership in order to identify and ascertain that goods conform to the stated quality and quantity. Moreover, the sacks used by traders are themselves non-standardized and subject to moral hazard. The incidence and significance of the cost of bagging, like that of personal travel by the trader, suggests the presence of market failure in the facilitation of market exchange between buyers and sellers. Similar results were obtained by Gabre-Madhin (1998) in Ethiopian grain markets, where re-sacking is also customary, resulting in very high handling costs of $25 \%$. In Benin and Malawi, handling costs represent 12 to $13 \%$ of total costs. This lack of 
standardized sacks and of grades and standards for traded products leads to the need to off-load and transfer goods to different bags at each assembly point in the marketing chain, resulting in significant losses in economic welfare.

Commissions and tips account for $8 \%$ of variable costs in Benin but are negligible in Malawi. This reflects a major difference in the role of intermediaries between the two countries. As expected, short-term storage is less than $4 \%$ in both countries, confirming the lack of storage noted above. Market taxes assessed on quantities traded account for a very small fraction of variable costs: less than $3 \%$ of variable costs in both countries. With the exception of a very small number of traders, the use of telephone or other form of telecommunication is virtually non-existent in both countries, confirming the inability of traders to reliably conduct transactions without visually inspecting goods and physically being present for the transfer of ownership. This signals not only the lack of sophistication of agricultural trading in both countries but also the significant constraints imposed by missing markets for market information and product certification.

\section{Figure 2a-b. The Composition of Marketing Costs in Benin and Malawi}

\section{a. Benin $(\mathrm{N}=609)$}

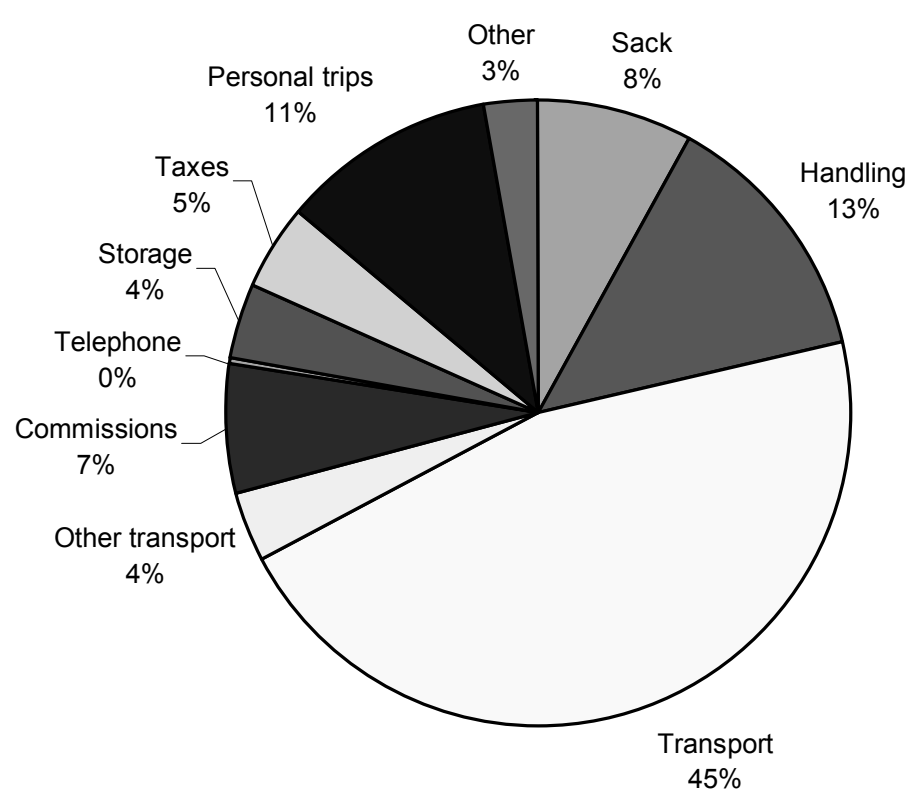


b. Malawi $(\mathrm{N}=622)$ :

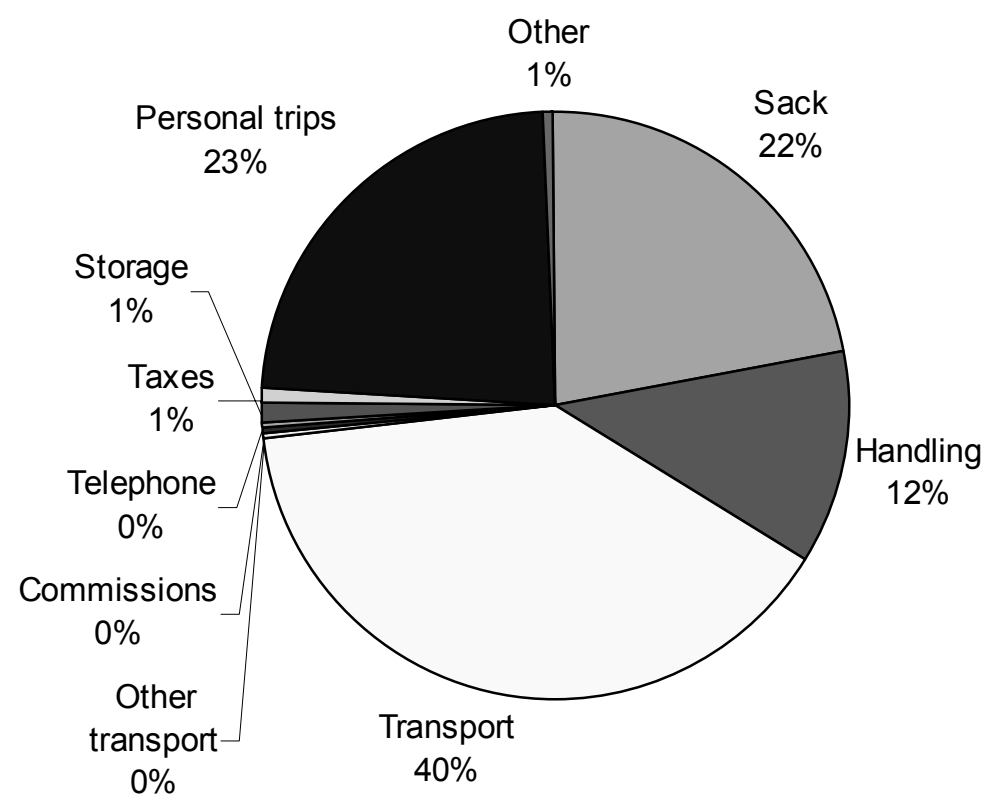

Operating costs. Data were also collected on fixed operating costs. Average operating costs amount to round $\$ 550$ per year in Benin vs. $\$ 190$ in Malawi. Survey results show that, in Benin, fixed operating costs are dominated by vehicle maintenance and insurance. These costs, however, are incurred only by a very small fraction of the trader population, those with vehicles. The next most important fixed cost category is storage and pest control. These costs account for $21 \%$ (Malawi) to $34 \%$ (Benin) of fixed operating costs, but they affect only a fourth to a third of surveyed traders; others stock at their residence or at their own storage facility.

Taxes and fees amount to $44 \%$ of operating costs in Malawi, but as little as 5\% in Benin. Even in Malawi, however, the burden of taxation remains small: $\$ 84$ a year, compared to an average annual turnover of around $\$ 43000$. While very few traders pay income tax, market fees are paid by most of them$50 \%$ in Benin, $80 \%$ in Malawi. For small traders, market fees are the only form of operating cost they incur. 
Since market fees do not increase proportionally with trade volume, it affects primarily small to mediumsize traders; it is a regressive tax. Given that transport represents such a large component of traders' costs, we speculate that traders probably pay more taxes through gasoline taxes than through all other forms of taxation.

Other categories of operating costs such as wages and losses due to theft make small contributions to costs. Total wages represent an extra cost of $\$ 50$ per year in Benin and $\$ 110$ in Malawi. This amount is very small because so few traders employ paid workers and when they do, they pay them very little. Very few traders borrow money. When they do, they borrow for such short periods that interest charges are, on average, negligible. Losses due to theft average $\$ 22$ a year in both countries.

We also collected detailed information on commissions paid to various intermediaries. These costs are in principle included in variable costs, but we also collected the information separately. We again see that commissions are much more frequent in Benin than in Malawi. This is particularly true for buying agents and consignment agents. Benin traders spend on average four times more on commissions than Malawian traders. To verify the information on the costs incurred for personal travel, the information was collected separately as well. Results confirm that personal travel represents a sizeable share of total costs: 17 to $18 \%$ of total variable costs in both countries.

To summarize, the structure of operating costs is dominated by transport costs. What is unexpected is the large share of this transport cost covers the travel of the trader himself or herself. The need for thousands of traders to travel to the sale market in person - instead of placing an order over the phone -undoubtedly contributes to higher trading costs. 
Table 30. Annual Operating Costs (US\$) of Traders in Benin and Malawi ${ }^{\text {a }}$

\begin{tabular}{lrrrrrr}
\hline & \multicolumn{7}{c}{ Benin } \\
\hline & Mean & S.d. & Min. & Max. & Median & N \\
\hline Fixed costs: & & & & & & \\
Rental of shop/storage & 74 & 472 & 0 & 10342 & 0 & 663 \\
Pest control & 116 & 1363 & 0 & 30417 & 0 & 663 \\
Electricity & 1 & 10 & 0 & 167 & 0 & 663 \\
Telephone & 19 & 268 & 0 & 6667 & 0 & 663 \\
Maintenance of vehicles & 292 & 3425 & 0 & 83333 & 0 & 663 \\
Vehicle insurance & 24 & 150 & 0 & 2150 & 0 & 663 \\
Fees and market taxes & 30 & 155 & 0 & 2129 & 0 & 663 \\
Income tax on trading business & 1 & 9 & 0 & 183 & 0 & 663 \\
Total operating costs & 557 & 3881 & 0 & 85279 & 13 & 663 \\
Commissions to agents: & & & & & & \\
Buying agents & 254 & 903 & 0 & 12167 & 0 & 624 \\
Brokers & 71 & 458 & 0 & 6083 & 0 & 653 \\
Consignment agents & 87 & 255 & 0 & 2129 & 0 & 653 \\
Travel costs: & & & & & & \\
To purchase markets & 297 & 1421 & 0 & 30720 & 142 & 537 \\
To sales markets & 177 & 805 & 0 & 13905 & 30 & 414 \\
Loss due to theft & 22 & 140 & 0 & 2500 & 0 & 659 \\
Total wage bill & & & & & & 629 \\
\hline
\end{tabular}

\begin{tabular}{|c|c|c|c|c|c|c|}
\hline & \multicolumn{6}{|c|}{ Malawi } \\
\hline & Mean & S.d. & Min. & Max. & Median & $\mathrm{N}$ \\
\hline \multicolumn{7}{|l|}{ Fixed costs: } \\
\hline Rental of shop/storage & 19 & 102 & 0 & 2489 & 0 & 738 \\
\hline Pest control & 21 & 230 & 0 & 4148 & 0 & 737 \\
\hline Electricity & 10 & 129 & 0 & 3318 & 0 & 737 \\
\hline Telephone & 5 & 55 & 0 & 1227 & 0 & 737 \\
\hline Maintenance of vehicles & 47 & 430 & 0 & 8182 & 0 & 737 \\
\hline Vehicle insurance & 5 & 76 & 0 & 1591 & 0 & 737 \\
\hline Fees and market taxes & 69 & 336 & 0 & 8295 & 50 & 736 \\
\hline Income tax on trading business & 15 & 337 & 0 & 9091 & 0 & 733 \\
\hline Total operating costs & 188 & 806 & 0 & 11818 & 66 & 730 \\
\hline \multicolumn{7}{|l|}{ Commissions to agents: } \\
\hline Buying agents & 45 & 384 & 0 & 8295 & 0 & 735 \\
\hline Brokers & 52 & 433 & 0 & 8295 & 0 & 735 \\
\hline Consignment agents & 2 & 41 & 0 & 1091 & 0 & 734 \\
\hline \multicolumn{7}{|l|}{ Travel costs: } \\
\hline To purchase markets & 443 & 1348 & 0 & 23636 & 213 & 564 \\
\hline To sales markets & 1219 & 4843 & 0 & 47273 & 65 & 219 \\
\hline Loss due to theft & 22 & 121 & 0 & 2273 & 0 & 727 \\
\hline Total wage bill & 111 & 853 & 0 & 20739 & 0 & 726 \\
\hline
\end{tabular}


Table 31. Traders' Cost Structure by Working Capital in Benin and Malawi

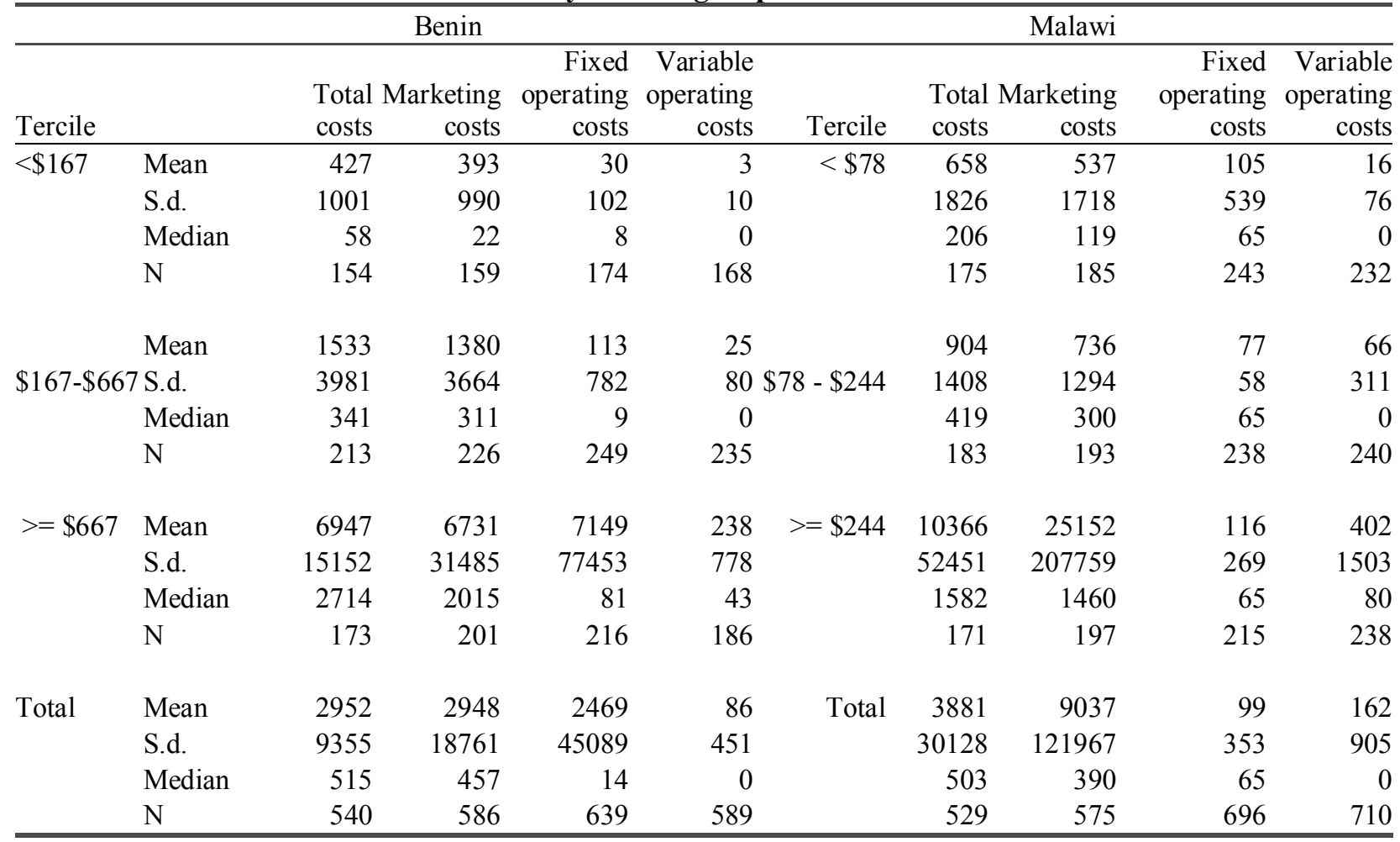

\subsection{Net Marketing Margins and Annual Profits}

Net Marketing Margins on Last Transaction. For the last transaction, net margins are obtained by subtracting total variable marketing cost from the gross marketing margin, which is equal to the price spread between purchase and sales price. Net margins in terms of dollars per ton are considerably higher (8.4 times) in Malawi, with a sample average of $\$ 194 /$ ton compared to $\$ 23$ in Benin. This supports our earlier findings that competition is greater in Benin. Net margins appear to vary significantly in both countries, with no discernible effect of firm assets or gender on net margin levels in either country.

Further, it is striking that $23 \%$ of traders in Benin and $8 \%$ in Malawi report a negative net margin. This is in part due to negative gross margins, where the price spread is negative, for $3 \%$ of the sample in Benin. However, beyond the relative small frequency of negative price spreads, it appears that a large proportion of traders, particularly in Benin, did not cover their costs in the last transaction. In part, this 
finding indicates the presence of competition, but it also suggests possible measurement error of the variable marketing costs. In particular, sources of error are the cost of personal travel, which covers the entire shipment. Personal travel costs are subject to economies of scale as well as of scope. This is because traders may take advantage of a trip to take care of personal business or to engage in other, more profitable, commercial activities, which are not captured in our measure of profit.

Table 32. Net Margins (\$/ton) by Firm Assets in Benin and Malawi

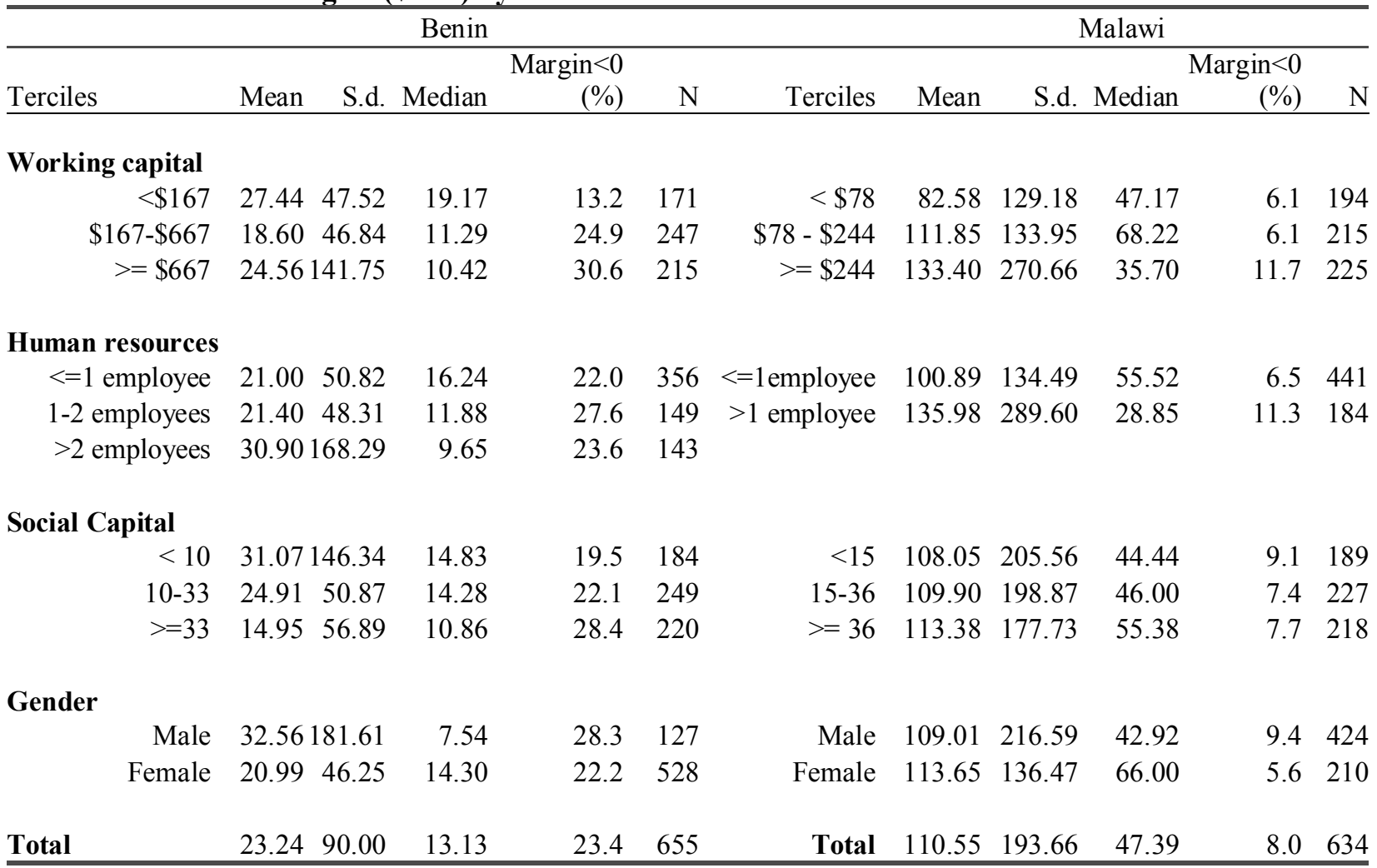

Annual Profits. We construct estimates of profits from trading. Profit is computed as the annual sales minus annual purchases minus annualized variable costs minus annual wages paid minus annual operating costs. In case agricultural trade only represents part of the revenue of the surveyed trader, annual purchases and sales were inflated accordingly. Traders who derive less than $10 \%$ of their annual revenue from agricultural trader are omitted. The resulting profit represents payments to self-provided 
factors of production such as working capital, owned storage facilities, equipment, and vehicles, and unpaid labor by the entrepreneur and family helpers.

Computed profits suffer from severe measurement error. This is because they are obtained by subtracting poorly measured costs from poorly measured revenues. Measurement errors therefore tend to compound themselves and individual measures of profit should be regarded with caution. Average profits, however, should provide a reasonable approximation of what profits from trading must look like in the two surveyed countries.

After eliminating the upper and lower one percent of the distribution, we find that $21 \%$ of surveyed traders do not cover their operations and wage costs out of annual sales (28\% in Benin, $15 \%$ in Malawi). Annual profits also vary dramatically across countries, with the median profit in Malawi -- $\$ 1003$-- nearly ten times higher than in Benin - $\$ 119$. For most Benin respondents, trade provides but a small return on entrepreneurship and capital. This suggests that competition is fierce in Benin, less so in Malawi.

Results show that traders' profits are non-negligible: $\$ 1340$ on average in Benin, $\$ 6140$ in Malawi. The difference between the two countries is significant ( $\mathrm{t}$ value of 6.03). Median profits, however, are much lower: $\$ 120$ in Benin, $\$ 1140$ in Malawi. This corresponds to an average profit rate on turnover of $6 \%$ in Benin and $14 \%$ in Malawi. Profits amount to $32 \%$ of the gross margin (difference between buying price and selling price) in Benin; the corresponding figure for Malawi is $57 \%{ }^{2}$. Median profit rates are $37 \%$ and $64 \%$, respectively. Since, if anything, Malawian traders have less equipment and working capital and use less family labor than their Benin counterparts, higher profit rates cannot be explained as higher payment to selfprovided factors of production. It therefore appears that Malawian traders are less competitive.

\footnotetext{
${ }^{2}$ To minimize bias, this figure is obtained after eliminating traders who do not derive all their revenue from agricultural trade.
} 
Table 33. Annualized Profits in Benin and Malawi ${ }^{\mathrm{a}}$

\begin{tabular}{|c|c|c|c|c|c|c|}
\hline & \multicolumn{4}{|c|}{ Benin } & \multirow[b]{2}{*}{ Median } & \multirow[b]{2}{*}{$\mathrm{N}$} \\
\hline & Mean & S.d. & Min. & Max. & & \\
\hline Profit rate on annual sales & $3.9 \%$ & $18.9 \%$ & $-114.8 \%$ & $57.7 \%$ & $5.5 \%$ & 559 \\
\hline \multirow[t]{3}{*}{ Annual profit $(\$)^{\mathrm{b}}$} & 1338.81 & 5537.11 & -9163.71 & 68593.59 & 119.05 & 559 \\
\hline & \multicolumn{4}{|c|}{ Malawi } & & \\
\hline & Mean & S.d. & Min. & Max. & Median & $\bar{N}$ \\
\hline Profit rate on annual sales & $14.1 \%$ & $18.2 \%$ & $-80.3 \%$ & $57.1 \%$ & $14.9 \%$ & 549 \\
\hline Annual profit $(\$)^{\mathrm{b}}$ & 6140.68 & 17989.06 & -4173.45 & 172689.50 & 1142.11 & 545 \\
\hline
\end{tabular}

${ }^{\mathrm{a}}$ Profit $=$ Gross margin - variable costs - operating costs - wage bill.

b At the time of survey, exchange rates were 1 US $\$=$ CFA 600 and 1 US $\$=$ MK 45.

These average profit rates mask a great deal of variation across traders. A large proportion of surveyed traders -- 20\% -- appear to be making losses. On the other hand, some traders appear to be making astronomical profits. It is unclear how much of this variation is due to measurement error, but the extent of it suggests that profits from trade are likely to be very variable. Agricultural trade is a risky venture.

Further analysis of absolute levels of annual profits broken down by firm assets and gender provides evidence of significant returns to working capital as well as to social capital in both countries. Median profits nearly double between working capital terciles in Benin and nearly triple in Malawi. Returns to social capital are also high in both countries, though somewhat lower than that of financial capital. In contrast to Malawi, profits are nearly half for traders in the middle tercile compared to the bottom tercile. This suggests that the one-person enterprises, typically of women retailers, are more profitable than the slightly larger firms. As firms grow beyond the threshold level of 2 employees, profitability then increases. Finally, as expected, male traders have considerably higher profit levels than women in both countries.

The figures below confirm that across countries for each type of firm asset and gender, traders in Malawi have considerably higher profit rates, defined as the ratio of annual profits to the value of annual sales, than their counterparts in Benin. What is also revealing is that, unlike the case of absolute profit levels, there is no clear pattern of the impact of assets on profit rates. 
Table 34. Annual Profits by Firm Assets in Benin and Malawi (\$)

\begin{tabular}{|c|c|c|c|c|c|c|c|c|c|}
\hline \multicolumn{6}{|c|}{ Benin } & \multicolumn{4}{|c|}{ Malawi } \\
\hline & Mean & S.d. & Median & $\mathrm{N}$ & & Mean & S.d. & Median & $\mathrm{N}$ \\
\hline \multicolumn{10}{|l|}{$\begin{array}{l}\text { Working } \\
\text { Capital }\end{array}$} \\
\hline$<\$ 167$ & 520.62 & 1875.13 & 79.20 & 145 & $<\$ 78$ & 737.24 & 1956.37 & 297.89 & 173 \\
\hline$\$ 167-\$ 667$ & 888.82 & 2706.06 & 133.86 & 210 & $\$ 78-\$ 244$ & 1994.70 & 4692.99 & 865.52 & 182 \\
\hline$>=\$ 667$ & 2737.89 & 10465.61 & 210.42 & 162 & $>=\$ 244$ & 9069.13 & 67011.87 & 2690.47 & 170 \\
\hline \multicolumn{10}{|l|}{ Human resources } \\
\hline$<1$ employee & 3213.70 & 11315.70 & 142.51 & 58 & 0-1 employee & 2815.60 & 10364.75 & 650.58 & 389 \\
\hline 1-2 employees & 778.78 & 4097.84 & 73.74 & 262 & $>1$ employee & 6890.15 & 73390.51 & 2086.36 & 136 \\
\hline$>2$ employees & 1500.48 & 6200.78 & 223.12 & 215 & & & & & \\
\hline \multicolumn{10}{|l|}{ Social capital } \\
\hline$<10$ & 81.54 & 1807.44 & 72.68 & 146 & $<15$ & 2698.08 & 7433.28 & 466.34 & 155 \\
\hline $10-33$ & 1053.35 & 3794.99 & 100.17 & 219 & $15-36$ & 4540.01 & 59066.08 & 767.73 & 194 \\
\hline$>=33$ & 2781.78 & 9693.72 & 273.96 & 170 & $>=36$ & 4166.85 & 22465.76 & 1428.90 & 176 \\
\hline \multicolumn{10}{|l|}{ Gender } \\
\hline Male & 3929.95 & 12442.11 & 291.25 & 103 & Male & 5002.94 & 47520.49 & 1252.62 & 339 \\
\hline Female & 712.65 & 2866.97 & 94.87 & 433 & Female & 1808.24 & 5690.83 & 425.17 & 186 \\
\hline Total & 1330.90 & 6145.03 & 102.83 & 536 & Total & 3871.10 & 38345.75 & 884.50 & 525 \\
\hline
\end{tabular}


Figure 3a-d Annual Profit Rates by Firm Assets in Benin and Malawi ${ }^{a}$
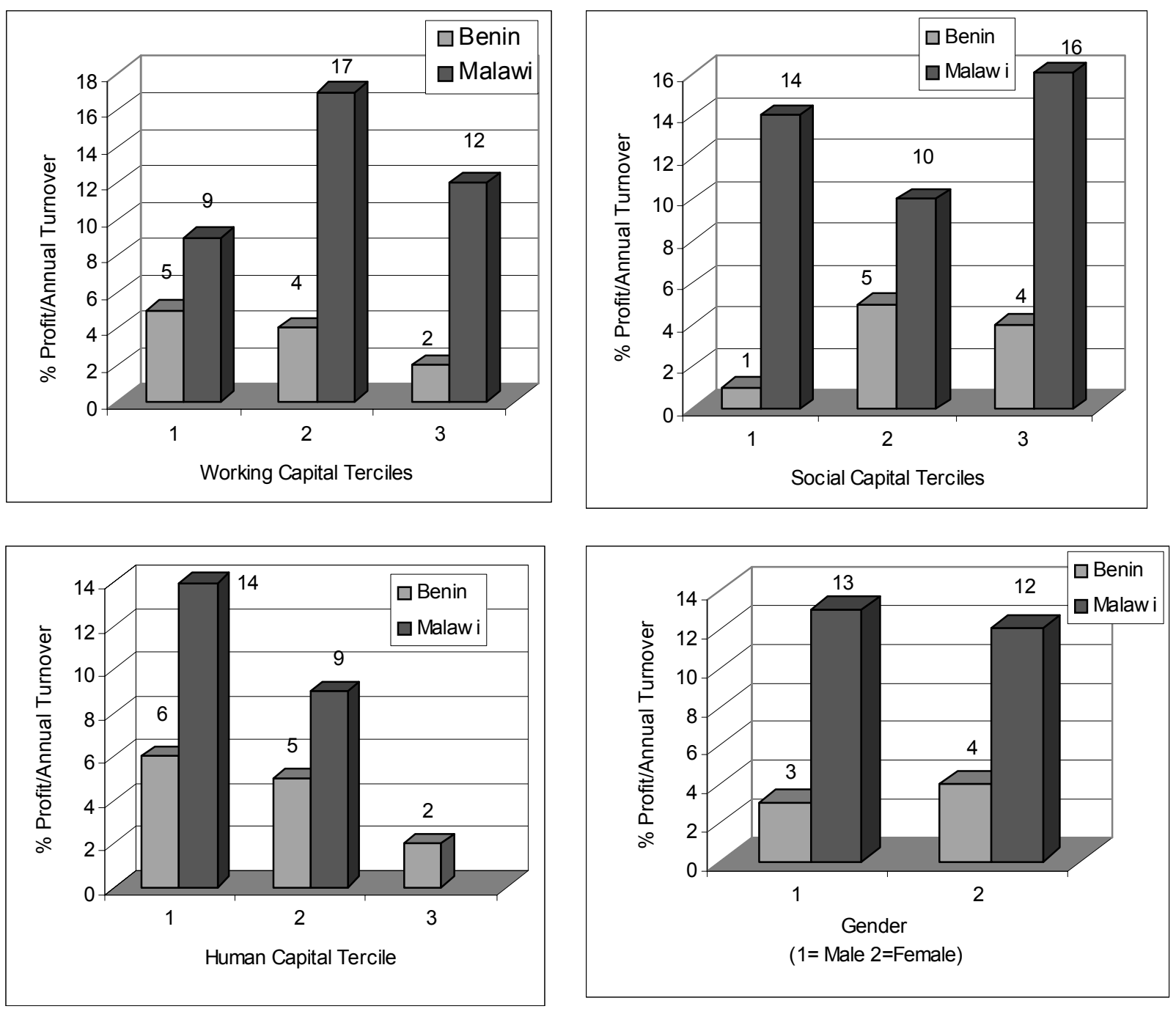

${ }^{\mathrm{a}}$ Profit rate $=\%$ annual profit/ value of sales. 


\section{CONCLUSIONS AND POLICY OPTIONS}

We have given a detailed description of how agricultural traders operate in Benin and Malawi, two countries fairly representative of western and eastern and southern Africa. Many of the features we have documented were well-known — small size of businesses, lack of equipment, rudimentary business practices, and the dominant role of transport costs. Other features were less well known, such as the importance of personal travel, bagging practices, the short distances over which most traders operate, and the incidence of theft and breach of contract.

We were also able to dispel some myths. For instance we documented the absence of speculative, inter-seasonal storage for the overwhelming majority of traders, and the relatively low returns to storage in general. We showed that advances from traders to farmers are of short duration—one to two weeks. Their main purpose is not to exploit farmers' need for cash in order to finance agricultural production, but rather a means for traders to secure future deliveries.

The picture that emerges from this analysis is one that is dominated by transport—-for goods and for traders. Because trading enterprises are small, the quantities they can gather from any one market are limited by what the trader can reliable locate, finance, and inspect. As a result, transport takes place in small vehicles - pick-up trucks for the most part. An inordinate amount of personal travel takes place as well, since traders must inspect the goods they purchase and payment is normally in cash upon delivery.

Surveyed traders appear to work effectively under the constraints they face, which are many-e.g., limited external finance, no brand names and trademarks, no certified quality, no organized commodity exchange, extremely decentralized production and consumption. They rely on networks to share information and discourage breach of contract and are able to perform an essential trading function in a flexible and expeditious manner. But the end result nevertheless is a costly system that provides a limited service to consumers and producers.

Another feature worth emphasizing is the simplicity of the equipment used by most traders. Few traders own scales or processing equipment. Storage often takes place at home. While a small minority owns 
vehicles, most traders rely on external providers to transport their goods and themselves. Agricultural goods are mostly transported in small pick-up trucks. These were shown to have higher costs. Most capital is tied up in inventories and, for some traders, in short-term credit to customers. Reliance on external finance is extremely limited. The only form of borrowing that is common in both countries is loans from friends and relatives to deal with short-term emergencies. Working capital, however, is not sufficient for commercial success if it is not combined with business contacts.

The modernization of agricultural trade requires that original solutions be found to the genuine problems that traders face. The only 'modern' technologies Benin and Malawian traders seem to be using at this point are motorized transport and pest control. Telephones and banks are ignored. Brand recognition, grading, and quality certification are non-existent. Brokers and agents are not organized in commodity exchanges. Quantities are not pooled for transport and storage so as to achieve returns to scale. Interseasonal and inter-regional arbitrage is outside the purview of most traders, who prefer to operate in a small territory on a day-by-day basis. By extension, an entire continent is fed using a rudimentary, costly, and risky set-up.

The information presented here provides some important insights as to how agricultural trade can be improved. Policy interventions can be conceived in four main areas: (i) increasing traders' asset base; (ii) reducing transaction risk; (iii) promoting more sophisticated business practices; and, (iv) reducing physical marketing costs.

\section{Increasing Traders' Assets}

One possible approach to reduce marketing costs and improve agricultural markets is to help traders invest in modern equipment. We were surprised by the virtual absence of scales and processing equipment (such as grain dryers and grading machines) and reliance on small-scale home storage. One possible interpretation is that traders do not invest in such equipment because it is not profitable. This may be true for small traders but is unlikely to be correct for large trading operations. We believe that these avenues should 
be explored. One should keep in mind, however, that as large traders get better equipped and hopefully more efficient, they should drive out some of the smaller traders, who predominantly tend to be women.

Improving access to external finance should also be attempted. It is shocking, for instance, to note that large traders do not even have an overdraft facility. For certain traders - those with adequate experience and good business contacts - access to more finance would undeniably help them grow and prosper. But we are not convinced that increasing widespread access to external finance would improve the efficiency of agricultural markets in general: easier finance may help some traders increase their market share and eliminate competitors, but need not result in lower prices for consumers or higher prices for producers. The reason is that business practices remain quite rudimentary, making it difficult if not impossible for trading operations to grow beyond a certain size and remain competitive.

Our results suggest that larger traders have higher margins. There are at least three possible explanations for this finding. First, it is possible that larger traders conduct more profitable operations, involving more risky and more capital intensive activities such as storage and long-distance transport. If this interpretation is correct, larger traders are more profitable on average because they capture returns to risk taking and scarce capital. A second possible interpretation is that agricultural trade, as it is currently practiced, is characterized by decreasing returns to scale: large traders have higher margins because they are inefficiently large. Normally, competition should weed out inefficient firms and align margins. But the forces of competition might be hindered by privilege and political clientelism.

Thirdly, large firms might have higher margins because they exert market power. The presence of a large number of small traders would normally be sufficient to discipline large traders. But the crude transaction practices of the competitive fringe compare to the slightly more efficient practices of large traders might result in increasing returns to scale. If this interpretation is correct, the fact that large firms with high margins coexist with small firms with low margins suggests that large firms act monopolistically: if they wanted, they could eliminate the competitive fringe by reducing their price. The fact that they do not is evidence of insufficient competition among large firms. 
In this respect the comparison between Benin and Malawi is instructive. Gross margins and unit profits are noticeably lower in Benin than in Malawi. At the same time there appears to be more competition and smaller trading firms in Benin. At prima facie, this would suggest that more competition favors smaller margins. Population density is also much higher in Benin and crop production is spread more evenly over the year. This implies more geographical concentration in traders' operations, and less need for storage. Together, these features could explain the lower costs of intermediation in Benin. These issues will be the object of further research.

\section{Reducing Transaction Risk}

Our work shows that rudimentary business practices can largely be blamed on transaction risk. Payment takes place at delivery, a practice that precludes invoicing and payment by check and complicates accounting. Goods have to be inspected upon delivery because the supplier is not trusted to provide a reliable account of the quality and quantity sold. Grain has to be physically moved from one bag to another at each sale transaction. This facilitates inspection but raises costs and slows down trade. Business networks have developed as a partial palliative to these problems, but they are insufficient to eliminate them. Besides, networks have other problems (Fafchamps 1999).

It is not entirely clear how in practice transaction risk can be reduced. The court system by itself is unlikely to suffice because agricultural market transactions are seldom large enough to go to court, assuming that breach of contract could be demonstrated and that the defendant has assets that can be foreclosed upon. One institutional innovation that could potentially reduce transaction risk would be for markets authorities to take a pro-active stance. Membership in traders association could in principle be used as a guarantee of good conduct. Traders shown to breach contracts would be ousted from the association. The existence of traders associations in Benin suggests that such approach might be possible by strengthening and advising existing associations.

Traders associations could also intervene in grading and quality certification. An association equipped with a grain dryer and simple grading equipment could bag and certify its products in a manner 
that is difficult to falsify. Reassured about the quality of the goods they purchase, buyers may be more willing to place orders by phone.

Another approach would focus on agents and brokers who could, in principle, serve as essential link between unknown buyer and seller. Gabre-Madhin (1998) has documented how this system works in the case of the Ethiopian grain market. A core of experienced brokers would be required before a commodity exchange could be set up. The existence of such an exchange would in turn facilitate the circulation of information by publicizing current and future grain prices. Albeit the creation ad nihilo of commodity exchanges in Benin and Malawi is not something we recommend for the near future, assisting the emergence of grain brokers coupled with grading and quality certification by traders' associations would lay the foundation for a commodity exchange in the more distant future.

\section{Promoting Sound Business Practices}

Benin and Malawian traders manage to feed the population of their respective country by collecting and distributing food among millions of producers and consumers. They do so in difficult circumstances and demonstrate great ingenuity. Perhaps even more remarkably, many of them appear to be making a living from their trading activity. All this notwithstanding, business practices appear inefficient. As argued earlier, exchange takes a cumbersome form. This enables a myriad of small traders to compete with larger ones. But cumbersome practices increase the costs of the entire marketing system.

The question is how to capture increasing returns to scale from modern trading practices. Put differently, how can we enable large traders to adopt modern transaction methods so that they can reduce their costs and drive small traders out. One possibility is to favor large traders directly, for instance through credit programs and restrictions to entry. These policies have been tried elsewhere and have generally failed to induce large traders to modernize and become more efficient. Another approach is to support the 'modernization' of trading practices irrespective of firm size. If modern practices are, as expected, efficiency enhancing, those traders that begin using them should grow and eventually displace others. One example of such approach would be to upgrade markets by installing telephones and faxes, providing cheap good 
quality sacks, and facilitating loading and off-loading. Simple processing equipment could also made available to traders, in exchange for a user fee. It is likely that some experimentation is required to identify suitable innovations - and the right sequence of innovations. A pilot project on market support would be the ideal vehicle for such experimentation.

\section{Reducing Physical Marketing Costs}

Physical marketing costs constitute the bulk of traders' costs. Although many of these physical costs are ultimately the result of transactions costs (e.g., the need for traders to travel to the point of purchase and sale), there is ample scope for lowering marketing costs by reducing transport costs. Various policies could be used to address the high cost of transport. Direct measures, such as reducing gasoline taxes, would undoubtedly have an effect, at the expense of much needed government revenues. Measures to improve the maintenance of rural feeder roads are urgently needed. Devolving maintenance to local administration is an option to study. Its corollary is that local administration must be granted taxing authority, e.g., the right to set up toll roads or other forms of road taxation.

Another innovation worth exploring is the expansion of transport brokerage services. We have shown that transport costs could be reduced by using larger trucks. This is currently difficult because of the small size and decentralized nature of traders' operations. Transport brokers would take possession of cargo, rent out space on large trucks, and deliver to traders in their sales market. Our observations suggest that such practices are already present, but not sufficiently widespread. We suspect that the fear of breach of contract is a strong obstacle to the development of these practices. Better trust between traders and transport brokers should greatly simplify the organization of transport, thereby reducing costs. 


\section{REFERENCES}

Badiane, O., F. Goletti, M. Kherallah, P. Berry, K. Govindan, P. Gruhn, and M. Mendoza. Agricultural Input and Output Marketing Reforms in African Countries. Final Donor Report. Washington, D.C.: International Food Policy Research Institute (IFPRI), 1997

Badiane O. and Shively G. E. "Spatial Integration, Transport Costs, and the Response of Local Prices to Policy Changes in Ghana", Journal of Development Economics, 56(2): 411-31, August 1998

Barrett C. B. "Food Marketing Liberalization and Trader Entry: Evidence from Madagascar", World Development, 25(5): 763-777, May 1997

Barrett, C.B. "Understanding uneven agricultural liberalisation in Madagascar." Journal of Modern African Studies 32(1994):449-76.

Beynon, J., S. Jones, and S. Yao. "Market reform and private trade in Eastern and Southern Africa." Food Policy 17(1992):399-408.

Bryceson, D.F. Liberalizing Tanzania's food trade: public and private faces of urban marketing policy 1939-88. Geneva, Switzerland: United Nations Research Institute for Social Development, 1993

Crow B. and Murshid K. "Economic Returns to Social Power: Merchants' Finance and Interlinkage in the Grain Markets of Bengladesh", World Develoment, 22(7): 1011-30, July 1994

Coulter, J. and C. Poulton. Cereal Market Liberalization in Africa. In Commodity Reforms: Background, Process, and Ramifications. Washington, D.C.: World Bank, 1999

Dercon S. "On Market Integration and Liberalisation: Method and Application to Ethiopia", Journal of Development Studies, 32(1); 112-143, October 1995

Dorward, A., J. Kydd, and C. Poulton. "The Baby and the Bathwater: Agricultural Parastatals Revisited." Paper presented at a symposium on the African Rural Crisis Revisited at the Annual Conference of the Agricultural Economics Society, Stranmillis University College, Queen's University of Belfast, 28 March 1999. London, UK: Agrarian Development Unit, Wye College, University of London, 3-28-1999

Fafchamps M. and Minten B. "Returns to Social Network Capital Among Traders", Department of Economics, Oxford University, Oxford, May 2000, (mimeograph)

Fafchamps M. and Minten B. "Social Capital and Agricultural Trade", American Journal of Agricultural Economics, 2001a, (forthcoming)

Fafchamps M. "The Role of Business Networks in Market Development in Sub-Saharan Africa", in Community and Market in Economic Development, Masahiko Aoki and Yujiro Hayami (eds.), Stanford, March 1999, (forthcoming)

Fafchamps M. and Minten B. "Relationships and Traders in Madagascar", Journal of Development Studies, 35(6): 1-35, August 1999 
Fafchamps M. and Minten B. "Property Rights in a Flea Market Economy", Economic Development and Cultural Change, $2001 \mathrm{~b}$ (forthcoming)

Gabre-Madhin, E. Transfer Costs of Cereals Marketing in Mali: Implications for Mali's Regional Trade in West Africa. M.S. Thesis. East Lansing, MI: Michigan State University, 1991

Gabre-Madhin, E. Transaction Costs, Contractual Choices, and Institutions in the Ethiopian Grain Market. Ph.D. Dissertation. Stanford, CA: Stanford University, 1998.

Granovetter M. "The Economic Sociology of Firms and Entrepreneurs", in The Economic Sociology of Immigration: Essays on Networks, Ethnicity, and Entrepreneurship, pp. 128-165, Alejandro Portes (Ed.), Russell Sage Foundation, New York, 1995

Jayne, T.S. and S. Jones. "Food Marketing and Pricing Policy in Eastern and Southern Africa: A Survey." World Development 25(1997):1505-1527.

Jones, S. Food Markets in Developing Countries: What Do We Know? Working Paper No.8. Oxford, UK: Food Studies Group, University of Oxford, 1996

Kherallah, M., C. Delgado, E. Gabre-Madhin, N. Minot, and M. Johnson. Agricultural Market Reforms in Sub-Saharan Africa: A Synthesis of Research Findings. Washington, DC: IFPRI, 2000.

Mazumdar D. and Mazaheri A. "The Structure of Labor Market and Wages in African Manufacturing", University of Toronto, Toronto, December 1998 (mimeograph)

Negassa, A. Vertical and spatial integration of grain markets in Ethiopia: Implications for grain market and food security policies. Working Paper 9. Addis Ababa, Ethiopia: Ministry of Economic Development and Cooperation, 1998

Seppala, P. Food marketing reconsidered: an assessment of the liberalization of food marketing in SubSaharan Africa. Research for Action No.34. Helsinki, Finland: United Nations University, World Institute for Development Economics Research (UNU/WIDER), 1997

Tadelis S. "What's in a Name? Reputation as a Tradable Asset", American Economic Review, 89(3): 548563, June 1999

Tripp R. and Pal S. "Information Exchange in Commercial Seed Markets in Rajasthan", AgREN, ODI Agricultural Research and Extension Network, London, July 1998, Network Paper No.83

Velenchik A. D. "Government Intervention, Efficiency Wages, and the Employer Size Wage Effect in Zimbabwe", Journal of Development Economics, 53(2): 305-338, August 1997 